\title{
Anti-Cancer Natural Products and Their Bioactive Compounds Inducing ER Stress-Mediated Apoptosis: A Review
}

\author{
Changmin Kim and Bonglee Kim * \\ Department of Pathology, College of Korean Medicine, Graduate School, Kyung Hee University, 1 Hoegi-dong, \\ Dongdaemun-gu, Seoul 130-701, Korea; ckdals4302@khu.ac.kr \\ * Correspondence: bongleekim@khu.ac.kr; Tel.: +82-2-961-9217
}

Received: 25 June 2018; Accepted: 1 August 2018; Published: 4 August 2018

\begin{abstract}
Cancer is the second biggest cause of death worldwide. Despite a number of studies being conducted, the effective mechanism for treating cancer has not yet been fully understood. The tumor-microenvironment such as hypoxia, low nutrients could disturb function of endoplasmic reticulum (ER) to maintain cellular homeostasis, ultimately leading to the accumulation of unfolded proteins in ER, so-called ER stress. The ER stress has a close relation with cancer. ER stress initiates unfolded protein response (UPR) to re-establish ER homeostasis as an adaptive pathway in cancer. However, persistent ER stress triggers the apoptotic pathway. Therefore, blocking the adaptive pathway of ER stress or facilitating the apoptotic pathway could be an anti-cancer strategy. Recently, natural products and their derivatives have been reported to have anti-cancer effects via ER stress. Here, we address mechanisms of ER stress-mediated apoptosis and highlight strategies for cancer therapy by utilizing ER stress. Furthermore, we summarize anti-cancer activity of the natural products via ER stress in six major types of cancers globally (lung, breast, colorectal, gastric, prostate and liver cancer). This review deepens the understanding of ER stress mechanisms in major cancers as well as the suppressive impact of natural products against cancers via ER stress.
\end{abstract}

Keywords: natural products; bioactive compounds; cancer; endoplasmic-reticulum stress; unfolded protein response; apoptosis

\section{Introduction}

Cancer is a group of diseases that undergo unregulated cell growth and proliferation without stopping [1]. Although overall survival term is increased slightly due to early detection, cancer-related mortality is the second biggest cause of death worldwide [2]. The International Agency for Research on Cancer (IARC) reported that 14.1 million new cancer cases and 8.2 million deaths took place worldwide in 2012, and 21.7 million cancer incidences and 13 million deaths were predicted in 2030. Among several types of cancers, lung, breast, colorectal, gastric, prostate, and liver cancer were selected as the major cancers in human being. These cancers represent $55 \%$ of the global cancer incidence burden in 2012 [3].

The mechanisms of cancer occurrence and progression are not fully understood yet. The proliferation of cancer originated from its ability to avoid programmed cell death, so-called apoptosis [4]. That is why induction of apoptosis in cancer has been identified as a target for treatment of cancer $[5,6]$. Up to now, induction of apoptosis is conducted by two main apoptotic pathways: intrinsic and extrinsic pathway [7]. Intrinsic pathway is mitochondria-mediated apoptosis which is mediated by cytochrome $C$ release and activation of caspase-9, stimulating effector caspases, caspase-3. Extrinsic pathway is death receptor (DR)-mediated apoptosis which activates the FAS-associated death domain (FADD) and 
forms the death-inducing signaling complex (DISC), which processes downstream caspases including caspase-8,-7,-6, and $-3[8,9]$. However, studies have identified that the accumulation of unfolded proteins in endoplasmic reticulum (ER) and its cellular stress response is involved in apoptosis, indicating influence of ER on cell fate as a third subcellular compartment [10].

\section{Overview of ER Stress; A Double-Edged Sword-Cell Survival or Death?}

ER is an organelle in the eukaryotic cell that is responsible for protein synthesis and calcium $\left(\mathrm{Ca}^{2+}\right)$ signaling [11]. It also provides a suitable environment for lipid, steroid, and cholesterol biosynthesis. Moreover, the main roles of ER include maintenance of homeostasis in intracellular $\mathrm{Ca}^{2+}$ storage and the folding of protein destined to be secreted on the plasma membrane [12]. Proteins are translocated into ER lumen and undergo post translational modification for fidelity of synthesis, folding and correcting function. After passing ER, proteins are properly folded by a network of chaperones [13].

However, extra-cellular environmental challenges such as reactive oxygen species (ROS), hypoxia, and nutrients deprivation could induce disturbance in cellular redox regulation of ER, leading to an imbalance in homeostasis. Thus, the physiological function of ER and the ER protein-folding environment are impaired, ultimately resulting in the accumulation of unfolded protein in the lumen of the ER-namely, ER stress [10]. Prior studies have demonstrated that both ER stress and the activation of unfolded protein response (UPR) are associated with pathologic processes, including neurodegenerative diseases, cardiovascular disease, and cancer [14]. Because of the rapid expansion of malignant neoplasm, cancer cells are exposed to low nutrients, poor vascularization, and hypoxia so that ER stress-related proteins including glucose-regulated protein 78 (GRP78)/binding protein (BiP), glucose-regulated protein 94 (GRP 94), ER associated degradation (ERAD), protein disulphide isomerase (PDI), activating transcription factor 6 (ATF6), inositol-requiring protein 1 (IRE1), $\alpha$-x-box binding protein 1 (XBP1), protein kinase RNA-like ER kinase (PERK) and eukaryotic initiation factor 2 (eIf $2 \alpha)$ are overexpressed in many types of cancer cells [15-17]. In response to ER stress on early phase, the cell initiates UPR to modulate proper protein folding and degradation of unfolded protein as an adaptive pathway for survival. Under ER stress, GRP78/BiP, which originally binds to the luminal domain of three ER transducer sensors: IRE1, PERK, and ATF6, dissociates from these three ER transducer sensors. The three ER-localized transmembrane signal-transducers of UPR; ATF6, IRE1 and PERK detect accumulation of unfolded proteins and initiate to restore and maintain the ER homeostasis [18]. Moreover, ERAD is increased to attenuate unfolded protein accumulation, enhancing protein folding capacity in ER and ER chaperones (GRP 94, GRP78/BiP, calnexin), which are elevated to stabilize protein folding. However, if ER stress is prolonged to the extent that UPR is unable to cope with unfolded proteins, UPR is promoted to be turned into apoptotic machineries by transducing apoptotic downstream pathways through ATF6, PERK, and IRE1 signaling pathways [19].

\section{Anti-Cancer Strategy Based on Adaptive Pathway of ER Stress in Cancer Growth}

Cancer cells evolve UPR to mitigate the ER stress condition as a survival strategy for progression [20]. Also, UPR in cancer is reported to have significant roles in having resistance to chemotherapy or radiation $[17,21]$. Therefore, one therapeutic rationale regarding suppression of cancer is to facilitate the accumulation of unfolded proteins by inhibiting components of UPR involved in survival response, ultimately leading to apoptosis [22] (Figure 1). 


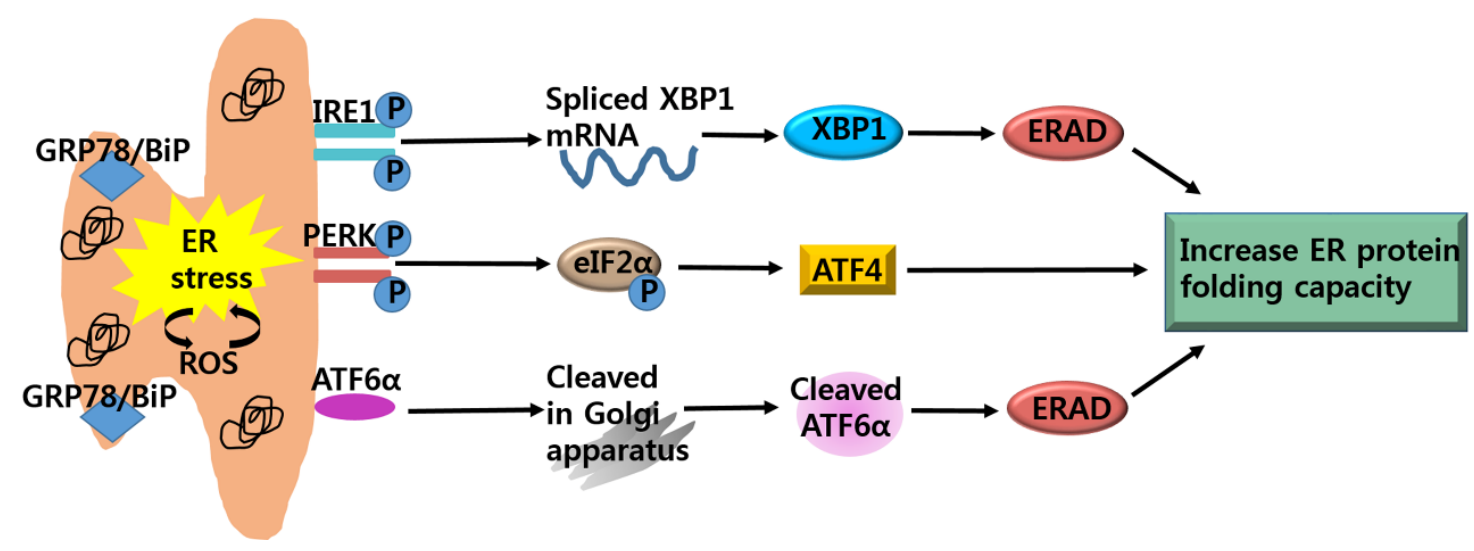

Figure 1. Adaptive pathways of endoplasmic reticulum (ER) stress. ER stress is induced by an accumulation of unfolded proteins in the ER lumen. During ER stress, glucose-regulated protein 78 (GRP78)/ binding protein (BiP) dissociates from its interaction with the three ER stress sensors, inositol-requiring protein 1 (IRE1), protein kinase RNA-like ER kinase (PERK), and activating transcription factor 6 (ATF6), which become activated. IRE1 mediates splicing of $\alpha$-x-box binding protein 1 (XBP1), which is responsible for the upregulation of ER associated degradation (ERAD). PERK phosphorylates eIF2 $\alpha$ and induce activating transcription factor 4 (ATF4), which is involved in restoring ER homeostasis. ATF6 $\alpha$ cleaved by specific Golgi resident proteases, increase expression of UPR genes and ERAD. Eukaryotic initiation factor 2 (eIf2); protein kinase RNA-like ER kinase (PERK).

\subsection{Anti-Cancer Strategy; Targeting ATF6 $\alpha$-GRP78/BiP Signaling}

A first modulator of ER stress signaling is ATF6 $\alpha$-GRP78/BiP. During ER stress conditions, dissociation of GRP78/BiP from ATF6 allows this protein to translocate to Golgi apparatus where it is cleaved by specific Golgi resident proteases [23]. This process forms ATF6 $\alpha$, which produces active transcription factors that are involved in up-regulating ER chaperones and ERAD [24]. In addition, ATF6 $\alpha$ contributes to transcription factor XBP1, which targets the ERAD [25] (Figure 1). Further, the expression of GRP78/BiP is elevated particularly in liver, colon, prostate, breast, lung, and gastric cancer [26-28]. The elevated expression of GRP78/BiP is reported to correlate with cancer proliferation, chemotherapy resistance, and poor patient survival rate by modulating accumulation of unfolded protein folding [29-31]. In addition, GRP78/BiP induces angiogenesis by activating the potent pro-angiogenic factor, vascular endothelial growth factor A (VEGF-A) [32]. Recently, studies have confirmed that knockdown of GRP78/BiP by siRNA can inhibit carcinogenesis and sensitize cancer cells to chemotherapeutic agents as well as ER stress [33-35]. The GRP78/BiP inhibitor exerted cytotoxicity against leukemia [36] and glioma cancer cells [34]. These observations suggest that during ER stress, inhibition of the ATF6-GRP78/BiP signaling pathway could be a strategy for cancer therapy [37]. For example, the knockout of GRP78 resulted in decreased proliferation rates of glioma cells and suppressed PTEN null prostate tumorigenesis and AKT oncogenic pathway [34,38].

\subsection{Anti-Cancer Strategy; Targeting IRE1 $\alpha-X B P 1$ Signaling}

A second modulator of ER stress signaling is IRE1 $\alpha$-XBP1. Two isoforms of IRE1, IRE1 $\alpha$ and IRE1 $\beta$, have been identified. IRE1 $\alpha$ is expressed in all cell types, but the expression of IRE1 $\beta$ is specifically restricted to the intestinal epithelium [39,40]. In cells undergoing ER stress, activation of IRE1 $\alpha$ stimulates an endoribonuclease that splices XBP1 mRNA to produce mature XBP1. XBP1 encodes an active leucine zipper (bZiP) transcriptions factor that generates transcription of genes 
involved in ERAD components as well as genes involved in redox homeostasis and oxidative stress response (Figure 1) [41,42]. The involvement of the IRE1 $\alpha-X B P 1$ signaling in cancer progression has been the subject of many studies. Upregulated XBP1 expression is observed in various human cancers including breast cancer and hepatocellular carcinoma [43]. XBP1-deficient cancer cells showed hypersensitivity to ER stress or hypoxia condition [41]. Moreover, expression of the dominant-negative form of IRE1 $\alpha$ or inhibition of XBP1 by siRNA induces reduction in angiogenesis during tumorigenesis and in cancer growth in xenografts model $[15,44,45]$. Additionally, inhibition of IRE1 $\alpha-X B P 1$ enhances apoptosis by down-regulating several genes involved in UPR and generates reactive oxygen species (ROS) in XBP1-deficient cells [15]. These results provide evidences that deactivation of the IRE1 $\alpha-X B P 1$ [46] could be a target of anticancer therapy. For instance, IRE1 $\alpha$ inhibitor rendered resistant human glioblastoma cells susceptible to oxidative stress [47]. Inhibition of IRE1 $\alpha$ decreased endonuclease activity, increasing cytotoxic activity against human multiple myeloma in vitro and in vivo [48].

\subsection{Anti-Cancer Strategy; Targeting PERK-eIF2 $\alpha$-ATF4 Signaling}

A third modulator of ER stress signaling is the PERK-elf $2 \alpha$ signaling pathway. Under ER stress conditions, activation of PERK phosphorylates eIF2 $\alpha$ at Ser51 [49]. Phosphorylated eIF2 $\alpha$ shuts down protein influx into the ER lumen and attenuates mRNA translation, reducing protein synthesis [50,51]. The activation of PERK-eIF2 $\alpha$ increases the translation of a number of mRNAs encoding activating transcription factor 4 (ATF4) [52]. ATF4 promotes cell-survival by controlling amino acid biosynthesis and transport function, as well as antioxidant stress responses [53]. PERK-eIF2 $\alpha$-ATF4 signaling pathway is responsible for cancer growth and resistance against curative treatment. The UPR signaling pathway through the PERK-eIF2 $\alpha$-ATF4 signaling pathway also increases tolerance in cancer cells to hypoxic stress [17]. In addition, the PERK-eIF2 $\alpha$-ATF4 signaling pathway in cancer cells mediates the upregulation of VEGF-A transcription [17]. Recently, it has been reported that PERK-deficient cells are hypersensitive to ER stress [54], and inhibition of PERK suppressed cancer cells which are resistant to radiation in vivo [55]. These results suggest that suppression of PERK-eIF2 $\alpha$-ATF4 signaling pathways could be a target of cancer therapy. For example, transformed mouse embryonic fibroblasts from the PERK-deficient animals and HT29 colorectal carcinoma cells with dominant-negative PERK had lower survival rates under hypoxic conditions than wild type control cells [56]. And these cells displayed smaller cancer-formation and increased the level of apoptotic activity in hypoxic areas, compared to wildtype cells [17]. In addition, PERK-deficient cancer cells exhibited declined ability to induce angiogenesis in response to hypoxic stress [57].

\section{Anti-Cancer Strategy Based on Apoptotic Pathway of ER Stress in Cancer Growth}

If ER stress persists or is aggravated, cancer cells fail to re-establish ER homeostasis via UPR, ER stress switches from pro-survival to pro-apoptotic condition [58]. Therefore, facilitation of ER stress to initiate the apoptosis pathway could be a therapeutic strategy for anti-cancer activity [14,59] (Figure 2).

\subsection{Anti-Cancer Strategy; Targeting CHOP-Mediated Apoptosis}

During the prolonged ER stress condition, PERK is activated and phosphorylates elF2 $\alpha$ [60]. Phosphorylated elF2 $\alpha$ subsequently activates ATF4 which targets the expression of apoptotic effector, CHOP (C/EBP-homologous protein; known as GADD153; GENE name Ddit3) [61]. Furthermore, ATF6 is also activated and transcriptionally induces CHOP [62]. CHOP-mediated cell death entails the induction of a variety of genes that may potentiate apoptosis, including GADD34 and ERO1 $\alpha$ [63]. GADD34, a transcriptional target of CHOP, encodes a subunit of protein phosphatase that promotes dephosphorylation of eIF2 $\alpha$ that leads resumption of protein synthesis, in turn increasing the load of proteins [64]. Accordingly, ER stress activates the UPR to initiate downstream of apoptotic pathways. In addition, $\mathrm{CHOP}$ is thought to elevate the expression of Ero1 $\alpha$, which catalyzes the re-oxidation of PDI, leading to hyper-oxidizing conditions in the ER [59]. The CHOP-induced expression of ERO1 $\alpha$ 
activates the ER $\mathrm{Ca}^{2+}$ release channel, inositol 1,4,5-triphosphate (IP3) receptor (IP3R) [65]. Then, cytoplasmic $\mathrm{Ca}^{2+}$ released from the ER triggers the activation of calcium/calmodulin-dependent protein kinase II (CaMKII), ultimately resulting in the induction of apoptosis pathways [66]. Furthermore, CHOP-mediated apoptosis is involved in extrinsic pathway through up-regulating DR5 along with capase-8 activation, which cleaves Bid (tBid) and translocates it to mitochondria $[67,68]$. In addition, $\mathrm{CHOP}$ is shown to decrease the expression of anti-apoptotic $\mathrm{Bcl}-2$ and $\mathrm{Bcl}-\mathrm{xL}$ proteins, while increasing the expression of pro-apoptotic proteins including Bak, Bax, BIM (Bcl-2-like protein 11), PUMA (p53 upregulated modulator of apoptosis) and NOXA (PMAIP1) (Figure 2) [69,70]. These studies imply that up-regulation of $\mathrm{CHOP}$ expression could be an attractive target for anti-cancer therapy. For example, CHOP-deficiency elevates cancer development in a $\mathrm{Kras}^{\mathrm{G} 12 \mathrm{~V}}$-induced mouse model of lung carcinoma [71]. And hepatocyte-specific CHOP deletion causes cancer growth in a mouse model of hepatocellular carcinoma [72].

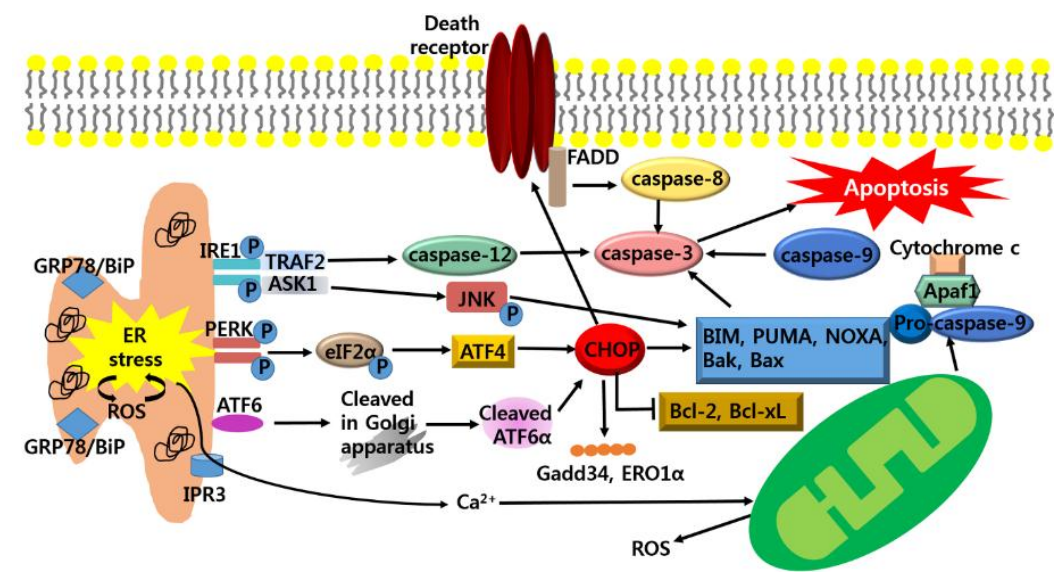

Figure 2. Apoptotic pathways of ER stress. If the adaptive UPR pathway fails to restore homeostasis, chronic ER stress induces apoptosis pathways. ER stress activates IRE1 and activated IRE recruits TNF receptor-associated factor2 (TRAF2) and apoptosis signal-regulating kinase 1 (ASK1). TRAF2 stimulates the activation of caspase-12 and ASK1 elicits the phosphorylation of c-Jun-N terminal kinase (JNK) to activate the pro-apoptotic protein; Bcl-2-like protein 11 (BIM), Bak, Bax and inhibits the anti-apoptotic protein; B-cell lymphoma 2 (Bcl-2), Bcl-2-associated X protein (Bax). Activation of PERK and ATF6 leads to up-regulation of CHOP that regulates Gadd34, ERO1 $\alpha$ and activates the pro-apoptotic protein; BIM, Bak, Bax, p53 upregulated modulator of apoptosis (PUMA), NOXA as well as DR which increase caspase-8. Also, ER stress generates ROS and this facilitates the accumulation of unfolded protein in the ER. ER stress-induced $\mathrm{Ca}^{2+}$ release into cytosol leads to depolarization of the inner mitochondrial membrane, resulting in Mitochondrial ROS. Apoptosis protease-activating factor 1 (Apaf1); FAS-associated death domain (FADD).

\subsection{Anti-Cancer Strategy; Targeting IRE1-Mediated Apoptosis}

Under chronic ER stress, IRE1 $\alpha$ is induced to activate the mitogen-activated protein (MAP) kinase (MARK) [73]. The IRE1 $\alpha$ binds with the adaptor protein, TNF receptor-associated factor2 (TRAF2). IRE1 $\alpha$-TRAF2 complex triggers the activation of caspase-12, which is homologous to human caspase-4 [74]. Caspase-12 translocates from the ER to the cytosol, where it initiates cleavage of procaspase-9, in turn, activating the effector caspase, caspase-3 [75,76]. IRE1 $\alpha /$ TRAF2 activates ASK1 (apoptosis signal-regulating kinase 1), which subsequently promotes activation and phosphorylation of c-Jun-N terminal kinase (JNK) [77]. The Phosphorylation of JNK activates BIM, Bak, Bax and inhibits the Bcl-2 and Bcl-xL (Figure 2) [78,79]. These data implicate that the triggering IRE1-mediated apoptosis could be a strategy for anti-cancer therapy. For instance, ER stress-mediated apoptosis was reduced in IRE1-deficient mouse embryonic fibroblasts [80]. And deactivation of ER stress-mediated apoptosis in JNK inhibitor treated wild-type-mouse embryonic fibroblasts was confirmed [81]. 


\subsection{Anti-Cancer Strategy; Targeting Generation of ROS-Mediated Apoptosis}

When ER stress persists, it hyper-oxidizes the ER lumen, resulting in $\mathrm{H}_{2} \mathrm{O}_{2}$ leakage into the cytoplasm and inducing ROS [82,83]. Furthermore, under oxidative environment, leakage of $\mathrm{Ca}^{2+}$ from ER lumen is stimulated, increasing calpains and $\mathrm{Ca}^{2+}$ burden in mitochondria $[84,85]$. The $\mathrm{Ca}^{2+}$ uptake in mitochondria depolarizes the inner mitochondrial membrane, leading to mitochondrial ROS generation [86]. Then, BH3-only proteins, Bak and Bax, oligomerize and insert themselves into the outer mitochondrial membrane to increase permeabilization, resulting in the release of cytochrome c [87]. When cytochrome $\mathrm{c}$ is released with the formation of APAF-1 (apoptosis protease-activating factor 1) and procaspase-9 [88]; caspase-3 [89], apoptosis-inducing factor (AIF) and endonuclease G (EndoG) are activated [90]. In general, cancer cells intrinsically have more ROS compared to normal cells. Therefore, elevated generation of ROS render cancer cells more susceptible to ER stress, which contributes to ER stress-mediated apoptosis [91]. Thus, the generation of ROS could be a target of anti-cancer therapy. In vitro, ROS-dependent ER stress activation and mitochondrial-related apoptotic pathway were identified in MDA-MB-231 and MCF-7 cell lines with treatment of berberine [92]. Pardaxin-triggered ROS-dependent ER stress and its apoptotic activation via ER stress were inhibited by NAC treatment [93].

\section{Anti-Cancer Effects of Natural Products via ER Stress}

The standardized treatments of cancer consist of surgery, chemotherapy, radiation therapy and immunotherapy. These are utilized in accordance with the characters and stages of the cancers. Although the main purpose of anti-cancer treatments is to kill the cancer cells without damaging normal cells, cancer treatments possess limited efficacy and exert their actions on both malignant and normal cells, resulting in adverse effects on patients, including anemia, loss of appetite, delirium and peripheral neuropathy. Thus, the development of effective treatment which has anti-cancer activity with less adverse effects is still needed [94,95]. From the history of drug discovery, natural product-derived compounds could be a promising treatment due to their characteristic to induce apoptosis more commonly in cancers compared to normal cells [96,97]. In fact, several conventional chemotherapeutic agents including Taxol, epothilones, vinca alkaloids originate from the resource of natural products [98]. Currently, as ER stress response is proven to have both an adaptive pathway and apoptotic pathway, modulation of ER stress could be an anti-cancer strategy. Therefore, researchers have focused on the interplay between natural products and anti-cancer effect via ER stress in malignant cells in vitro and in vivo [99-101]. Hence, in this review article, anti-cancerous mechanisms of natural products on the most common cancer types via modulation of ER-stress are discussed; lung, breast, colorectal, gastric, prostate, liver cancer, which represent $55 \%$ of the global incidence burden in $2012[2,3]$.

\subsection{Search Methodology}

Researches regarding the ER stress-mediated apoptotic effect of natural product on cancers were collected from PUBMED/MEDLINE and Google Scholar. Upon searching for appropriate studies, we include 'ER stress, apoptosis, UPR, natural product, cancers' for keywords. We collected studies which fit into the criteria: (1) researches based on in vitro or in vivo or clinical trials to prove ER-stress mediated apoptosis of natural product (2); researches that demonstrated reliable statistical analysis data ( $p$ values that were less than 0.05 ); and (3) researches that were not upset by subsequent studies. The family names of natural products and herbs mentioned in this review are based on a reliable source. Natural product-derived compounds in this review were double-checked from the NCBI PubChem website for precision. 


\subsection{Natural Products Targeting ER Stress-Mediated Apoptosis in Lung Cancer}

Lung cancer is one of the leading causes of cancer-related death in the world and around 1.8 million new cases were estimated in 2012 [3]. Chemotherapy and radiation are the main treatments for lung cancer, which often become resistant to these treatments [102]. As a result, the majority of lung cancer patients suffer from severe side effects and ultimately succumb to death [103]. Therefore, there remains a need for developing a new therapeutic agent to improve the clinical outcomes. As UPR has a critical role in lung cancer viability and lung cancer death [104], researches have been implemented to prove ER stress-mediated anti-cancer activity of natural products against lung cancer cells (Table 1).

Enhanced expression of GRP78/BiP, CHOP, and caspase-3 in NCI-H460 cells were observed by treatment of Polyphyllin D (PD; a potent cytotoxic saponin isolated from Paris polyphylla), which suggests that Polyphyllin D-induced ER stress-mediated apoptosis [105]. Dehydrocostuslactone (DHE; sesquiterpene lactone extracted from the Saussurea lappa and Aucklandia lappa) activated PERK-CHOP and IRE1-JNK signaling pathways in both NCI-H460 and A549 cells through ER stress caused by induction of $\mathrm{Ca}^{2+}$ and ROS in the cytoplasm [106]. CHOP expression was upregulated in A549 cells, inducing apoptosis by treatment of brefeldin A (BFA; a macrocyclic lactone antibiotic synthesized from palmitate by a variety of fungi). However, NAC treatment considerably suppressed apoptosis induced by BFA treatment, indicating that BFA induced apoptosis is dependent on ROS [107]. $\omega$-Hydroxyundec-9-enoic acid ( $\omega$-HUA; a hydroxyl unsaturated fatty acid derivative isolated from the leaves of Oryza officinalis) suppressed the viability of H1299 cells through ROS-dependent ER stress, however, the reduced expression of CHOP was detected after NAC treatment [108]. Curcumin (a phenolic compound isolated from the Curcuma longa) elevated the level of CHOP, GRP78/BiP expression in NCI-H460 cells, which is associated with release of intracellular $\mathrm{Ca}^{2+}[109]$. Cantharidin (CTD; a natural terpenoid extracted from Mylabris phalerata Pallas) induced cytotoxic effects on NCI-H460 cells through ER stress along with the release of intracellular $\mathrm{Ca}^{2+}$, leading to mitochondrial dysfunction. Upregulation of cytochrome c, Bax, Endo G, AIF and cleaved caspase-3,-8 were observed in CTD treated NCI-H460 cells [110]. Also, CHOP expression in A549 and 95-D cells was elevated by furanodiene (FUR; a natural terpenoid isolated from Curcumae rhizome) [111]. Parthenolide (PTL; a sesquiterpene lactone derived from the feverfew) treatment upregulated ER stress by activating eIF2 $\alpha$-ATF4-CHOP signaling in A549, Calu-1, H1299, H1792, leading apoptosis. However, knockout of ATF4 by ATF4 siRNA reduced apoptosis, indicating that the expression of CHOP mediates PTL induced-apoptosis [112]. Anacardic acid (AA; a constituent of Anacardium occidentale) increased expression of CHOP, cleavage of caspase-12, and disturbed $\mathrm{Ca}^{2+}$ homeostasis in A549 cells, confirming AA as an ER stress inducer [113]. 
Table 1. Bioactive compounds from natural products that induce ER-stress-mediated apoptosis in lung cancer.

\begin{tabular}{|c|c|c|c|c|c|}
\hline Family Name & Compound & Cell Line & Duration/Dosage & Mechanism & Reference \\
\hline \multirow{2}{*}{ Paris polyphylla } & \multirow{2}{*}{ Polyphyllin D } & \multirow{2}{*}{ NCI-H460 } & \multirow{2}{*}{$1.8 \mu \mathrm{M}, 8 \mathrm{~h}$} & $\mathrm{CHOP} \uparrow, \mathrm{GRP} 78 / \mathrm{BiP} \uparrow, \mathrm{PDI} \uparrow$ & \multirow{2}{*}{ [105] } \\
\hline & & & & cleavage of caspase- $3,-4,-9,-12 \uparrow, \mathrm{Bax} \uparrow, \mathrm{Bcl}-2 \downarrow$ & \\
\hline \multirow{8}{*}{$\begin{array}{l}\text { Saussurea lappa and } \\
\text { Aucklandia lappa }\end{array}$} & \multirow{6}{*}{ Dehydrocostuslactone } & \multirow{3}{*}{ NCI-H460 } & \multirow{3}{*}{$15 \mu \mathrm{g} / \mathrm{mL}, 1 \mathrm{~h}$} & $\begin{array}{l}\text { release of intracellular } \mathrm{Ca}^{2+} \text { levels } \uparrow, \Delta \psi \mathrm{m} \downarrow, \mathrm{p} \text {-PERK } \uparrow, \mathrm{GRP} 78 / \mathrm{BiP} \uparrow, \mathrm{IRE} 1 \uparrow, \\
\mathrm{CHOP} \uparrow, \mathrm{XBP}-1 \uparrow\end{array}$ & \multirow{6}{*}[106]{} \\
\hline & & & & Cleavage of caspase- $4 \uparrow, \mathrm{JNK} \uparrow, \mathrm{MAPK} \uparrow$ & \\
\hline & & & & $\operatorname{ROS} \uparrow$ & \\
\hline & & \multirow{3}{*}{ A549 } & \multirow{3}{*}{$15 \mu \mathrm{g} / \mathrm{mL}, 1 \mathrm{~h}$} & $\begin{array}{l}\text { release of intracellular } \mathrm{Ca}^{2+} \uparrow, \Delta \psi \mathrm{m} \downarrow, \mathrm{p}-\mathrm{PERK} \uparrow, \mathrm{GRP} 78 / \mathrm{BiP} \uparrow, \mathrm{IRE} 1 \uparrow, \mathrm{CHOP} \uparrow, \\
\text { XBP1 } \uparrow\end{array}$ & \\
\hline & & & & JNK $\uparrow$, MAPK $\uparrow$, cleavage of caspase- $4 \uparrow$ & \\
\hline & & & & $\operatorname{ROS} \uparrow$ & \\
\hline & \multirow{2}{*}{ BrefeldinA } & \multirow{2}{*}{ A549 } & \multirow{2}{*}{$1 \mu \mathrm{M}, 36 \mathrm{~h}$} & p-PERK $\uparrow$, IRE $1 \alpha \uparrow$, ATF $4 \uparrow$, ATF $6 \uparrow, \mathrm{CHOP} \uparrow, \mathrm{GRP} 78 / \mathrm{BiP} \uparrow$ & \multirow{2}{*}{ [107] } \\
\hline & & & & cleavage of PARP $\uparrow$, cleavage of caspase- $2 \uparrow, \operatorname{Bid} \uparrow$ & \\
\hline \multirow{3}{*}{ Oryza officinalis } & \multirow{3}{*}{$\begin{array}{l}\omega \text {-Hydroxyundec-9-enoic } \\
\text { acid }\end{array}$} & \multirow{3}{*}{ H1299 } & \multirow{3}{*}{$500 \mu \mathrm{M}, 24 \mathrm{~h}$} & $\mathrm{p}$-eIF $2 \alpha \uparrow, \mathrm{CHOP} \uparrow$ & \multirow{3}{*}{ [108] } \\
\hline & & & & cleavage of caspase- $6,-9 \uparrow$, cleavage of PARP $\uparrow$ & \\
\hline & & & & $\operatorname{ROS} \uparrow$ & \\
\hline \multirow{3}{*}{ Curcuma longa } & \multirow{3}{*}{ Curcumin } & \multirow{3}{*}{ NCI-H460 } & \multirow{3}{*}{$25 \mu \mathrm{M}, 24 \mathrm{~h}$} & release of intracellular $\mathrm{Ca}^{2+} \uparrow, \Delta \psi \mathrm{m} \downarrow, \mathrm{CHOP} \uparrow, \mathrm{GRP} 78 / \mathrm{BiP} \uparrow$ & \multirow{3}{*}{ [109] } \\
\hline & & & & Bcl- $2 \downarrow, \mathrm{Bcl}-\mathrm{xL} \downarrow$, cytochrome $\mathrm{c} \uparrow$, cleavage of caspase- $3,-8,-9 \uparrow, B A X \uparrow, B A D \uparrow$ & \\
\hline & & & & $\operatorname{ROS} \uparrow$ & \\
\hline \multirow{3}{*}{ Mylabris phalerata Pallas } & \multirow{3}{*}{ Cantharidin } & \multirow{3}{*}{$\mathrm{H} 460$} & \multirow{3}{*}{$10 \mu \mathrm{M}, 24 \mathrm{~h}$} & $\begin{array}{l}\text { release of intracellular } \mathrm{Ca}^{2+} \uparrow, \Delta \psi \mathrm{m} \downarrow, \mathrm{GRP} 78 / \mathrm{BiP} \uparrow, \operatorname{IRE} 1 \alpha \uparrow, \operatorname{IRE} 1 \beta \uparrow, \mathrm{ATF} 6 \alpha \uparrow \text {, } \\
\text { XBP1 } \uparrow \text {, calpain } \uparrow,\end{array}$ & \multirow{3}{*}{ [110] } \\
\hline & & & & Bcl-xL $\downarrow$, cleavage of caspase-3,-8,-4 $\uparrow$ cytochrome c $\uparrow B A X \uparrow$, AIF $\uparrow$, Endo G $\uparrow$ & \\
\hline & & & & $\operatorname{ROS} \uparrow$ & \\
\hline Curcumae Rhizoma & Furanodiene & A549, 95-D & $80 \mu \mathrm{M}, 24 \mathrm{~h}$ & $\mathrm{CHOP} \uparrow, \mathrm{BIP} \uparrow$ & [111] \\
\hline \multirow{2}{*}{ Tanacetum parthenium $\mathrm{L}$. } & \multirow{2}{*}{ Parthenolide } & \multirow{2}{*}{$\begin{array}{l}\text { A549, Calu-1, } \\
\text { H1299, H1792 }\end{array}$} & $20 \mu \mathrm{M}, 24 \mathrm{~h}$ & ATF $4 \uparrow, p-e I F 2 a \uparrow$, eIF $2 \alpha \uparrow$ & [112] \\
\hline & & & & cleavage of caspase- $3,-8,-9 \uparrow$, cleavage of PARP $\uparrow$ & \\
\hline Anacardium occidentale & Anacardic acid & A549 & $3.0 \mu \mathrm{g} / \mathrm{mL}, 18 \mathrm{~h}$ & $\begin{array}{l}\text { release of intracellular } \mathrm{Ca}^{2+} \uparrow, \Delta \psi \mathrm{m} \downarrow, \mathrm{GRP} 78 / \mathrm{BiP} \uparrow, \mathrm{CHOP} \uparrow, \operatorname{IRE} 1 \alpha \uparrow \mathrm{ATF} 6 \uparrow, \\
\text { p-PERK } \downarrow, \mathrm{p} \text {-eIF } 2 \alpha \downarrow\end{array}$ & [113] \\
\hline & & & & cleavage caspase- $12 \uparrow$ & \\
\hline
\end{tabular}

Glucose-regulated protein 78 (GRP78); binding protein (BiP); protein disulphide isomerase (PDI); protein kinase RNA-like ER kinase (PERK); reactive oxygen species (ROS); inositol-requiring protein 1 (IRE1); $\uparrow$ - increasing concentration; $\downarrow$ - decreasing concentration; activating transcription factor 4 (ATF4); activating transcription factor 6 (ATF6); B-cell lymphoma 2 (Bcl-2), Bcl-2-associated X protein (Bax); X-ox binding protein 1 (XBP-1); c-Jun-N terminal kinase (JNK); mitochondrial membrane potential ( $\Delta \psi \mathrm{m}$ ); C/EBP-homologous protein (CHOP); $\alpha$-x-box binding protein 1 (XBP1); apoptosis-inducing factor (AIF); and eukaryotic initiation factor 2 (eIf2). 


\subsection{Natural Products Targeting ER Stress-Mediated Apoptosis in Breast Cancer}

Female breast cancer is the most common malignancy in women and the most frequently diagnosed cancer globally. 1.67 million cases were estimated in 2012, ranking as the second most common cancer world-wide [3]. Until now, most of the therapeutic drugs for breast cancer target the early stage of cancer cells; still there is no available therapeutic options for advanced breast cancer [103]. Thus, the development of more effective anti-cancer agents for breast cancer is imperative. Since the UPR is involved in execution of pro-survival or pro-death decision [114], many studies have been performed to test ER stress-mediated anti-cancer activity of natural products using breast cancer cell lines [115] (Table 2).

BFA, isolated from the fungus Eupenicillium brefeldianum, upregulated PERK, CHOP, BIM and downregulated Bcl-2 in MDA-MB-231 cells. These results suggest that mitochondrial dysfunction is involved in BFA-induced ER stress-mediated apoptosis [116]. Activation of elF2 $\alpha$, GRP94, GRP78/BiP, and CHOP in MCF7 cells was demonstrated by cryptotanshinone (a constituent of Salvia miltiorrhiza Bunge) treatment. Moreover, cryptotanshinone-induced ER stress sensitized MCF7 cells to anti-cancer agents including TNF $\alpha$, cisplatin, etoposide and 5-FU [117]. Saxifragifolin D (SD; an oleanane type pentacyclic triterpenoid isolated from Androsace umbellate) increased expression of CHOP, JNK and cytochrome $\mathrm{c}$ in both MCF-7 and MDA-MB-231 cells through induction of $\mathrm{Ca}^{2+}$ and ROS in the cytoplasm, resulting in induction of ER stress [118]. Prodigiosin (a bacterial tripyrrole red-colored pigment produced by Serratia marcescens) was proven to have potent cytotoxicity against MCF7, MDA-MB-231 and T-47D cells through ER stress in terms of CHOP expression. Treatment of prodigiosin up-regulated CHOP, cleavage of PARP and decreased Bcl-2. However, decreased cleavage of PARP and increased Bcl-2 were noted after CHOP siRNA treatment, indicating CHOP-dependent apoptosis [119]. Fucoidan (a polysaccharide extracted from brown seaweed such as Cladosiphon okamuranus and Fucus evanescens) facilitated ER stress by activating eIF2 $\alpha$, CHOP along with suppressing IRE1, XBP1 in MDA-MB-231 cells. Additionally, Fucoidan triggered mitochondrial dysfunction, resulting in Bax and cleavage of caspase-3 [120]. Tocotrienols (a subgroup of vitamine E) promoted increased of CHOP, JNK, cleavage of caspase-3,-8 in MDA-MB-231 and MCF-7 cells. These results indicated that ER stress by Tocotrienols treatment is associated with mitochondria and DR5-mediated apoptosis [101]. Ethanol extract of Brazilian red propolis was reported to activate apoptosis against MCF-7 cells via facilitating ER stress and mitochondria-mediated apoptosis, resulting in CHOP expression, cleavage of caspase-3, Bax, and downregulation of Bcl-xL, Bcl-2 [121]. Expression of CHOP, PERK and ROS was increased in MDA-MB-231 and MCF-7 cells by treatment of ampelopsin (AMP; a main bioactive constituent of Ampelopsis grossedentata). However, NAC treatment triggered inhibition of CHOP expression, indicating that AMP-induced ER stress-mediated apoptosis is dependent on ROS [122]. 
Table 2. Bioactive compounds from natural products that induce ER stress-mediated apoptosis in breast cancer.

\begin{tabular}{|c|c|c|c|c|c|}
\hline Family Name & Compound & Cell Line & Duration/Dosage & Mechanism & Reference \\
\hline \multirow{2}{*}{$\begin{array}{l}\text { Eupenicillium } \\
\text { brefeldianum }\end{array}$} & \multirow{2}{*}{ Brefeldin A } & \multirow{2}{*}{ MDA-MB-231 } & \multirow{2}{*}{$1 \mu \mathrm{g} / \mathrm{mL}, 24 \mathrm{~h}$} & IRE1 $\alpha \uparrow$, PERK $\uparrow$, CHOP $\uparrow$, calnexin $\downarrow$ & \multirow{2}{*}{ [116] } \\
\hline & & & & BIM $\uparrow$, cleavage of PARP $\uparrow$, Bcl- $2 \downarrow$, & \\
\hline \multirow{3}{*}{ Salvia miltiorrhiza Bunge } & \multirow{3}{*}{ Cryptotanshinone } & \multirow{3}{*}{ MCF7 } & \multirow{3}{*}{$10 \mu \mathrm{M}, 24 \mathrm{~h}$} & p-eIF $2 \alpha \uparrow$, GRP94 $\uparrow$, GRP7 9 , CHOP $\uparrow$ & \multirow{3}{*}{ [117] } \\
\hline & & & & cleavage of PARP $\uparrow$, cleavage of caspase $3 \downarrow$ & \\
\hline & & & & $\operatorname{ROS} \uparrow$ & \\
\hline \multirow{5}{*}{ Androsace umbellata } & \multirow{5}{*}{ Saxifragifolin } & \multirow{3}{*}{ MDA-MB-231 } & \multirow{3}{*}{$5 \mu \mathrm{M}, 24 \mathrm{~h}$} & IRE1 $\alpha \uparrow$, calnexin $\uparrow$, calpain $\uparrow, \mathrm{XBP} 1 \uparrow, \mathrm{CHOP} \uparrow, \mathrm{GRP} 78 / \mathrm{BiP} \uparrow$ & \multirow{5}{*}{ [118] } \\
\hline & & & & cleavage of PARP $\uparrow$, cleavage of caspase- $3,-9 \uparrow, B a x \uparrow$, cytochrome $C \uparrow, p-J N K \uparrow$ & \\
\hline & & & & ROS $\uparrow$ & \\
\hline & & \multirow{2}{*}{ MCF7 } & \multirow{2}{*}{$5 \mu \mathrm{M}, 24 \mathrm{~h}$} & IRE1 $\alpha \uparrow$, Calnexin $\uparrow$, calpain $\uparrow, \mathrm{XBP}-1 \uparrow, \mathrm{GRP} 78 / \mathrm{BiP} \uparrow, \mathrm{CHOP} \uparrow$ & \\
\hline & & & & cytochrome c $\uparrow$ & \\
\hline \multirow{2}{*}{ Serratia marcescens. } & \multirow{2}{*}{ Prodigiosin } & \multirow{2}{*}{$\begin{array}{l}\text { MCF7 } \\
\text { MDA-MB-231T-47D }\end{array}$} & \multirow{2}{*}{$100 \mu \mathrm{M}, 24 \mathrm{~h}$} & GRP78 $\uparrow$, CHOP $\uparrow, p-I R E 1 \uparrow, I R E 1 \uparrow, p-e I F 2 a \uparrow$, eIF2a $\uparrow$, ATF6 $\uparrow$ & \multirow{2}{*}{ [119] } \\
\hline & & & & cleavage of PARP $\uparrow, \mathrm{p}-\mathrm{JNK} \uparrow, \mathrm{JNK} \uparrow, \mathrm{BCL}-2 \downarrow$ & \\
\hline \multirow{6}{*}{ Fucus vesiculosus } & \multirow{2}{*}{ Fucoidan } & \multirow{2}{*}{ MDA-MB-231 } & \multirow{2}{*}{$100 \mu \mathrm{g} / \mathrm{mL}, 72 \mathrm{~h}$} & CHOP $\uparrow$, ATF $4 \uparrow$, p-eIF $2 \alpha \uparrow$, GRP78 $/$ BiP $\downarrow$, p-IRE $1 \downarrow$, XBP1 $\downarrow$ & \multirow{2}{*}{ [120] } \\
\hline & & & & Bax $\uparrow$, CaMK II $\uparrow$, cleavage of caspase- $3,-12 \uparrow$, cleavage of PARP $\uparrow$ & \\
\hline & \multirow{4}{*}{$\gamma$-tocotrienol } & \multirow[b]{2}{*}{ MDA-MB-231 } & \multirow[b]{2}{*}{$40 \mu \mathrm{M}, 16 \mathrm{~h}$} & $\mathrm{CHOP} \uparrow, \mathrm{ATF} 4 \uparrow, \mathrm{GRP} 78 / \mathrm{BiP} \uparrow, \mathrm{XBP} 1 \uparrow$ & \multirow{4}{*}[101]{} \\
\hline & & & & $\begin{array}{l}\text { cleavage of PARP } \uparrow \text {, cleavage of caspase- } 3,-8,-9 \uparrow, D R 5 \uparrow, J N K \uparrow, p-J N K, C-J u n \uparrow, \\
\text { p38 MAPK } \uparrow\end{array}$ & \\
\hline & & \multirow[b]{2}{*}{ MCF-7 } & \multirow[b]{2}{*}{$40 \mu \mathrm{M}, 16 \mathrm{~h}$} & $\mathrm{CHOP} \uparrow, \mathrm{GRP} 78 / \mathrm{BiP} \uparrow, \mathrm{XBP} 1 \uparrow$ & \\
\hline & & & & $\begin{array}{l}\text { cleavage of PARP } \uparrow \text {, cleavage of caspase-8,-9 } \uparrow, J N K \uparrow, p-J N K \uparrow, C-J u n \uparrow, D R 5 \uparrow, \\
\text { p38 MAPK } \uparrow\end{array}$ & \\
\hline \multirow{2}{*}{ Brazilian Red propolis } & \multirow{2}{*}{$\begin{array}{l}\text { Ethanol extract of } \\
\text { Brazilian Red propolis }\end{array}$} & MCE-7 & $20 \mu \mathrm{g} / \mathrm{mL} 24 \mathrm{~h}$ & $\mathrm{CHOP} \uparrow$ & [121] \\
\hline & & $\mathrm{MCF-7}$ & $20 \mu \mathrm{g} / \mathrm{mL}, 24 \mathrm{n}$ & cleavage of caspase- $3 \uparrow$, Bax $\uparrow$, BcL-xL $\downarrow$, BcL- $2 \downarrow$ & \\
\hline Ampelopsis grossedentata & Ampelopsin & MCF-7 & $60 \mathrm{uM} .24 \mathrm{~h}$ & GRP78 $/ \mathrm{BiP} \uparrow, \mathrm{p}-\mathrm{PERK} \uparrow, \mathrm{p}$-eIF $2 \alpha \uparrow, \mathrm{ATF} 6 \uparrow, \mathrm{CHOP} \uparrow$ & [122] \\
\hline Ampetopsis grosseaentata & Ampeiopsin & MDA-MB-231 & $60 \mu \mathrm{M}, 24 \mathrm{n}$ & $\operatorname{ROS} \uparrow$ & {$[122]$} \\
\hline
\end{tabular}

Bcl-2-like protein 11 (BIM); death receptor (DR5). 


\subsection{Natural Products Targeting ER Stress-Mediated Apoptosis in Colorectal Cancer}

Colorectal cancer is one of the leading causes of malignant neoplasm-related death in the world [3]. Around 1.3 million new cases were estimated, ranking as the third most common cancer in the world. Although early stage colon cancer is treatable, it is known to be resistant to chemotherapeutic drugs, which is linked with poor patient prognosis [123]. As UPR is involved in regulating colorectal cancer cell fates [124], many researches have been performed to test ER stress-mediated anti-cancer potential effects of natural products using colorectal cancer cells (Table 3).

Curcumin enhanced expression of CHOP, JNK, cytochrome c, and FADD in HT-29 cells. These results indicate that the release of intracellular $\mathrm{Ca}^{2+}$, mitochondrial dysfunction and DR5 are associated with curcumin-induced ER stress-mediated apoptosis [125]. 2-(3,4 dihydroxyphenylethanol) ethanol (DPE; phenol antioxidant derived from olive oil) induced apoptosis on HT-29 cells via ER stress, activating PERK-eIF2 $\alpha$-CHOP and IRE1-JNK signaling pathway. Moreover, mitochondria-mediated apoptotic factors including Bax, Bad, cytochrome c, and cleavage of caspase 3 were observed [126]. Suppression of Colo 205 cells viability was detected via BFA-induced ER stress in terms of CHOP expression [127]. Activation of eIF2 $\alpha, \mathrm{CHOP}$ cleavage of caspase- 4 was upregulated in HT29 cells by treatment of resveratrol (natural polyphenolic compound) [128]. Expression of PERK-ATF4-CHOP signaling was activated by treatment of zerumbone (ZER; sesquiterpene purified isolated from the Zingiber zerumbet Smith). Also, ZER up-regulated DR5 expression in both HCT116-p53null cells and SW480 cells, eventually activating caspase-8 [129]. Guttiferone H (derived from Garcinia xanthochymus) elevated expression of CHOP along with cleavage of caspases-3,-7 in HCT116 cells [130]. Inhibition of HCT116 cells viability following fucoidan (derived from Cladosiphon okamuranus and Fucus evanescens) treatment was observed, which is induced by upregulation of elF2 $\alpha$-CHOP expression along with inhibition of IRE1-XBP1 [120]. Piperine (from Piper nigrum Linn and Piper longum Linn) generated ROS, CHOP, JNK, cytochrome c in HT-29 cells. These findings indicate that ER stress-mediated apoptosis by piperine is linked with mitochondrial dysfunction [131]. Potent anti-cancer activity of flavokawain B (derived from Alpinia pricei Hayata) against HCT116 cells was proven through ER stress in terms of CHOP expression. However, NAC treatment restored the inhibitory effects of Flavokawain B, suggesting that ROS generation is required for ER stress-mediated apoptosis [132]. 
Table 3. Bioactive compounds from natural products that induce ER stress-mediated apoptosis in colorectal cancer.

\begin{tabular}{|c|c|c|c|c|c|}
\hline Family Name & Compound & Cell Line & Duration/Dosage & Mechanism & Reference \\
\hline \multirow[b]{2}{*}{ Curcuma longa } & \multirow[b]{2}{*}{ Curcumin } & \multirow[b]{2}{*}{ HT-29 } & \multirow[b]{2}{*}{$40 \mu \mathrm{M}, 24 \mathrm{~h}$} & release of intracellular $\mathrm{Ca}^{2+}, \Delta \psi \mathrm{m} \downarrow, \mathrm{CHOP} \uparrow$ & \multirow[b]{2}{*}{ [125] } \\
\hline & & & & $\begin{array}{l}\text { cleavage of caspase- } 3,-7,-8,-9 \uparrow, \text { Fas } \uparrow, \text { FasL } \uparrow \text { FADD } \uparrow \text { Bid } \uparrow, \text { tBid } \uparrow, \mathrm{p}-\mathrm{JNK} \uparrow, \text { Bax } \\
\uparrow, \text { cytochrome c } \uparrow, \text { Bcl- } 2 \downarrow\end{array}$ & \\
\hline \multirow[b]{2}{*}{ Olea europaea } & \multirow{2}{*}{$\begin{array}{l}2-3,4 \\
\text { dihydroxyphenylethanol }\end{array}$} & \multirow[b]{2}{*}{ HT-29 } & \multirow[b]{2}{*}{$400 \mu \mathrm{M}, 16 \mathrm{~h}}$, & $\begin{array}{l}\text { release of intracellular } \mathrm{Ca}^{2+} \uparrow, \Delta \psi \mathrm{m} \downarrow, \mathrm{IRE} 1 \uparrow, \mathrm{XBP} 1 \uparrow, \mathrm{GRP} 78 / \mathrm{BiP} \uparrow, \mathrm{PERK} \uparrow, \\
\text { eIF } \alpha \uparrow, \mathrm{CHOP} \uparrow,\end{array}$ & \multirow[b]{2}{*}{ [126] } \\
\hline & & & & 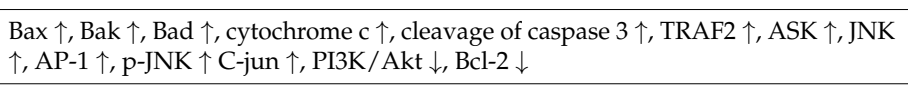 & \\
\hline \multirow[t]{3}{*}{$\begin{array}{l}\text { Eupenicillium } \\
\text { brefeldianum }\end{array}$} & Brefeldin A (BFA) & Colo 205 & $15 \mathrm{ng} / \mathrm{mL}, 24 \mathrm{~h}$ & $\mathrm{GRP} 78 \uparrow, \mathrm{XBP} 1 \uparrow, \mathrm{CHOP} \uparrow$ & [127] \\
\hline & \multirow{2}{*}{ Resveratrol } & \multirow{2}{*}{ HT29 } & \multirow{2}{*}{$50 \mu \mathrm{M}, 24 \mathrm{~h}$} & GRP78/BiP $\uparrow, \mathrm{CHOP} \uparrow, \mathrm{XBP} 1 \uparrow, \mathrm{eIF} 2 \alpha \uparrow$ & \multirow{2}{*}{ [128] } \\
\hline & & & & cleavage of caspase- $4 \uparrow$, cleavage of PARP $\uparrow$ & \\
\hline \multirow{6}{*}{ Zingiber zerumbet Smith } & \multirow{6}{*}{ Zerumbone } & \multirow{3}{*}{ HCT116-p53null } & \multirow{3}{*}{$20 \mu \mathrm{M}, 24 \mathrm{~h}$} & ATF4 $4, \mathrm{CHOP} \uparrow, \mathrm{GRP} 78 / \mathrm{BiP} \uparrow, \mathrm{p}$-PERK $\uparrow, \mathrm{PERK} \uparrow$ eIF $2 \alpha \uparrow, \mathrm{p}$-eIF2 $\alpha \uparrow$ & \multirow{6}{*}{ [129] } \\
\hline & & & & DR5 $\uparrow$ & \\
\hline & & & & $\operatorname{ROS} \uparrow$ & \\
\hline & & \multirow{3}{*}{ SW480 } & \multirow{3}{*}{$20 \mu \mathrm{M}, 24 \mathrm{~h}$} & ATF $4 \uparrow$, CHOP $\uparrow$, GRP78 $/$ BiP $\uparrow, p$-PERK $\uparrow$, PERK $\uparrow$ eIF $2 \alpha \uparrow$, p-eIF $2 \alpha \uparrow$ & \\
\hline & & & & DR5个 & \\
\hline & & & & $\operatorname{ROS} \uparrow$ & \\
\hline \multirow{2}{*}{ Garcinia xanthochymus } & \multirow{2}{*}{ Guttiferone $\mathrm{H}$} & \multirow{2}{*}{ HCT116 } & \multirow{2}{*}{$10 \mu \mathrm{g} / \mathrm{mL}, 24 \mathrm{~h}$} & $\mathrm{ATF} 4 \uparrow, \mathrm{XBP} 1 \uparrow, \mathrm{CHOP} \uparrow$ & \multirow{2}{*}{ [130] } \\
\hline & & & & 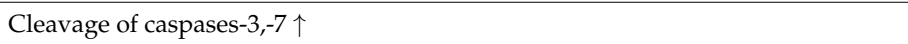 & \\
\hline \multirow{2}{*}{$\begin{array}{l}\text { Cladosiphon okamuranus } \\
\text { and Fucus evanescens }\end{array}$} & \multirow{2}{*}{ Fucoidan } & \multirow{2}{*}{ HCT116 } & \multirow{2}{*}{$100 \mu \mathrm{g} / \mathrm{mL}, 72 \mathrm{~h}$} & GRP78 $\uparrow, \mathrm{p}-\mathrm{CaMKII} \uparrow, \mathrm{eIF} 2 \mathrm{a} \uparrow, \mathrm{p}-\mathrm{eIF} 2 \alpha \uparrow, \mathrm{CHOP} \uparrow, \mathrm{IRE} 1 \downarrow, \mathrm{XBP} 1 \downarrow$ & [120] \\
\hline & & & & Cleavage of PARP $\uparrow$ & \\
\hline \multirow{3}{*}{$\begin{array}{l}\text { Piper nigrum Linn and } \\
\text { Piper longum Linn }\end{array}$} & \multirow{3}{*}{ Piperine } & \multirow{3}{*}{ HT-29 } & & IRE1 $\alpha \uparrow, \mathrm{CHOP} \uparrow, \mathrm{GPR} 78 / \mathrm{BiP} \uparrow$ & \\
\hline & & & $100 \mu \mathrm{g} / \mathrm{mL}, 72 \mathrm{~h}$ & cleavage of PARP $\uparrow$, cytochrome $\mathrm{c} \uparrow, \mathrm{JNK} \uparrow$, MAPK $\uparrow$, PI3K $/$ Akt $\downarrow$ & [131] \\
\hline & & & & $\mathrm{ROS} \uparrow$ & \\
\hline & & & & $\mathrm{CHOP} \uparrow, \mathrm{ATF} 4 \uparrow$ & \\
\hline Alpinia pricei Hayata & Flavokawain B & HCT116 & $50 \mu \mathrm{M}, 8 \mathrm{~h}$ & Bcl- $2 \downarrow$, MAPK $\uparrow$, PARP $\uparrow$, cytochrome $\mathrm{c} \uparrow, \mathrm{BIM} \uparrow, \mathrm{Bak} \uparrow$ & [132] \\
\hline & & & & $\operatorname{ROS} \uparrow$ & \\
\hline
\end{tabular}

TNF receptor-associated factor2 (TRAF2); apoptosis signal-regulating kinase 1 (ASK1); calcium/calmodulin-dependent protein kinase II (CaMKII); Fas ligand (FasL). 


\subsection{Natural Product Targeting ER Stress-Mediated Apoptosis in Gastric Cancer}

Gastric cancer emerged as one of the leading neoplasms in the world. Almost 1 million new cases of stomach cancer were estimated to have occurred in 2012, making it the fourth most common cancer world-wide [3]. Although progresses in surgery and chemotherapy for gastric cancer have been achieved, there is a high rate of cancer recurrences [133]. Therefore, novel effective therapeutic agents need to be developed. As UPR have a regulatory mechanism in either pro-survival or pro-apoptotic signals in gastric cancer [134], current studies have been performed to demonstrate ER-mediated anti-cancer activity of natural products (Table 4).

Curcumin enhanced CHOP, JNK, cytochrome c, FADD, DR5 and caspase- 8 in AGS cells. These results indicate that the release of intracellular $\mathrm{Ca}^{2+}$, mitochondrial dysfunction, extrinsic apoptotic pathway are involved in curcumin-induced ER stress [125]. Ultrafine (AM2; ethanolic extract of pulverized particles from Ulmus davidiana var. Japonica) upregulated GRP78/BiP, p-eIF2 $\alpha$, cleavage caspase-3,-6,-9 in both SNU-1 and SNU-484 cells [135]. Inhibition of MKN45 and SCM-1 cells viability through CHOP expression along with reduction of GRP94 was detected in Honokiol (isolated from the Magnolia officinalis) treatment [136]. Vitamin E succinate (RRR-a-tocopheryl succinate, VES) increased the level of CHOP, JNK, and caspase-12 and downregulated the expression of GRP94 in SGC-7901 cells [137]. Activation of CHOP, JNK and cleavage of caspase-4 were upregulated in SGC-7901 cells after treatment with a-Tocopheryl succinate (a-TOS; a derivative of natural vitamin E). NAC treatment decreased cell death by a-TOS, indicating that ER stress-mediated apoptosis by a-TOS is dependent on ROS generation [138]. Casticin (a major component obtained from Fructus viticis) induced elevation of CHOP, eIF2 $\alpha$, GRP78/BiP in BGC-823 cells as ER stress inducer. Additionally, Casticin upregulated DR5, leading to caspase-8 cleavage [139]. Expression of eIF2 $\alpha$-ATF4-CHOP signaling and JNK were enhanced in SGC-7901 cells by treatment of WZ35 (mono-carbonyl analogs of curcumin (MACs) via deletion of $\beta$-diketone moiety). Moreover, mitochondria-mediated apoptotic factor including Bax; cleavage of caspase-3 was observed. However, NAC treatment inhibited the effect of WZ35 by downregulating eIF2 $\alpha$-ATF4-CHOP signaling, Bax and cleavage of caspase- 3 . These results suggest that ROS generation may interplay with its ER stress-mediated apoptosis [140]. 
Table 4. Bioactive compounds from natural products that induce ER stress-mediated apoptosis in gastric cancer.

\begin{tabular}{|c|c|c|c|c|c|}
\hline Family Name & Compound & Cell Line & Duration/Dosage & Mechanism & Reference \\
\hline \multirow{2}{*}{ Curcuma longa } & \multirow{2}{*}{ Curcumin } & \multirow{2}{*}{ AGS } & \multirow{2}{*}{$20 \mu \mathrm{M}, 24 \mathrm{~h}$} & Release of intracellular $\mathrm{Ca}^{2+} \uparrow, \Delta \psi \mathrm{m} \downarrow, \mathrm{CHOP} \uparrow$ & \multirow{2}{*}{ [125] } \\
\hline & & & & cleavage of caspase- $-3,-7,-8,-9 \uparrow$, cytochrome $\mathrm{c} \uparrow$ & \\
\hline \multirow{4}{*}{$\begin{array}{l}\text { Ulmus davidiana } \\
\text { var. japonica }\end{array}$} & \multirow{4}{*}{ Ultrafine } & \multirow{2}{*}{ SNU-1 } & \multirow{2}{*}{$200 \mu \mathrm{g} / \mathrm{mL}, 24 \mathrm{~h}$} & GRP78/BiP $\uparrow, \mathrm{p}$-eIF2 $\alpha \uparrow$ & \multirow{4}{*}{ [135] } \\
\hline & & & & cleavage caspase- $-3,-6,-9 \uparrow$, cleavage of PARP $\uparrow$ & \\
\hline & & \multirow{2}{*}{ SNU-484 } & \multirow{2}{*}{$300 \mu \mathrm{g} / \mathrm{mL}, 24 \mathrm{~h}$} & $\mathrm{p}$-eIF2 $\alpha \uparrow, \mathrm{GRP} 78 / \mathrm{BiP} \uparrow$ & \\
\hline & & & & cleavage of caspase-3,-6,-9 $\uparrow$, cleavage of PARP $\uparrow$, Bcl- $2 \downarrow$, Bcl-xL $\downarrow$ & \\
\hline \multirow{4}{*}{$\begin{array}{l}\text { Magnolia } \\
\text { officinalis }\end{array}$} & \multirow{4}{*}{ Honokiol } & \multirow{2}{*}{ MKN45 } & \multirow{2}{*}{$40 \mu \mathrm{M}, 8 \mathrm{~h}$} & GRP94 $\downarrow$, CHOP $\uparrow$, calpain $\uparrow$ & \multirow{4}{*}{ [136] } \\
\hline & & & & cleavage of caspase- $-7,-12 \uparrow$, cleavage of PARP $\uparrow$ & \\
\hline & & \multirow{2}{*}{ SCM-1 } & \multirow{2}{*}{$40 \mu \mathrm{M}, 24 \mathrm{~h}$} & GRP94 $\downarrow$, CHOP $\uparrow$, calpain $\uparrow$ & \\
\hline & & & & cleavage of PARP $\uparrow$, & \\
\hline \multirow[t]{2}{*}{ vitamin $\mathrm{E}$} & \multirow[t]{2}{*}{ Vitamin E succinate } & \multirow[t]{2}{*}{ SGC-7901 } & \multirow[t]{2}{*}{$20 \mu \mathrm{g} / \mathrm{mL}, 24 \mathrm{~h}$} & $\begin{array}{l}\text { release of Intracellular } \mathrm{Ca}^{2+} \uparrow, \Delta \psi \mathrm{m} \downarrow \\
\mathrm{GRP} 78 / \mathrm{BiP} \uparrow, \mathrm{GRP} 94 \downarrow, \mathrm{PERK} \uparrow, \mathrm{ATF} 4 \uparrow, \mathrm{ATF} 6 \uparrow, \mathrm{XBP} 1 \uparrow, \mathrm{CHOP} \uparrow\end{array}$ & \multirow[t]{2}{*}{ [137] } \\
\hline & & & & cleavage of caspase- $4,-7,-12 \uparrow, \mathrm{p}-\mathrm{JNK} \uparrow, \mathrm{JNK} \uparrow$, cleavage of PARP $\uparrow$ & \\
\hline \multirow{3}{*}{ vitamin $\mathrm{E}$} & \multirow{3}{*}{ A-tocopheryl succinate } & \multirow{3}{*}{ SGC-7901 } & \multirow{3}{*}{$20 \mu \mathrm{g} / \mathrm{mL}, 24 \mathrm{~h}$} & GRP78/BiP $\uparrow, \mathrm{CHOP} \uparrow$ & \multirow{3}{*}{ [138] } \\
\hline & & & & cleavage of caspase- $4 \uparrow$ & \\
\hline & & & & $\operatorname{ROS} \uparrow$ & \\
\hline \multirow{3}{*}{ Fructus viticis } & \multirow{3}{*}{ Casticin } & \multirow{3}{*}{ BGC-823 } & \multirow{3}{*}{$1 \mu \mathrm{mol} / \mathrm{mL}, 24 \mathrm{~h}$} & $\mathrm{CHOP} \uparrow, \mathrm{p}$-eIF $2 \alpha \uparrow, \mathrm{eIF} 2 \alpha \uparrow, \mathrm{GRP} 78 / \mathrm{BiP} \uparrow$ & \multirow{3}{*}{ [139] } \\
\hline & & & & DR5 $\uparrow$, Bax $\uparrow$, Bid $\uparrow$, cleavage of caspase- $3,-8,-9 \uparrow$ & \\
\hline & & & & $\operatorname{ROS} \uparrow$ & \\
\hline & & & & ATF6 $\uparrow$, ATF $4 \uparrow, \mathrm{XBP} 1 \uparrow, \mathrm{CHOP} \uparrow$ & \\
\hline & 1-(4-hydroxy-3-methoxyphenyl)-5- & SGC-7901 & $10 \mu \mathrm{M}, 12 \mathrm{~h}$ & P-JNK $\uparrow$, Bax $\uparrow$, cleavage of caspase-3 $\uparrow$ Bcl-2 $\downarrow$ & \\
\hline Curcuma longa & (2-nitrophenyl)penta-1,4-dien-3-one & & & $\operatorname{ROS} \uparrow$ & [140] \\
\hline & $(\mathrm{WZ35})$ & SGC-7901xenograft in & WZ35 (orally, $50 \mathrm{mg} / \mathrm{kg}$ ) & $\mathrm{CHOP} \uparrow$ & \\
\hline & & $\begin{array}{l}\text { athymic BALB/Ca-nu/nu } \\
\text { female mice }\end{array}$ & for 28 days & cleavage of caspase- $3 \uparrow$ & \\
\hline
\end{tabular}




\subsection{Natural Products Targeting ER Stress-Mediated Apoptosis in Prostate Cancer}

Prostate cancer is the second most common cancer in men, and an estimated 1.1 million cases were diagnosed worldwide in 2012, making it the fourth leading cancer [3]. Due to early detection and new treatment options, quality of life of prostate cancer patients has been improved. However, most of the patients with prostate cancer suffer from aggressive and refractory cancer, with very poor prognosis [141]. Since UPR has been demonstrated to have an influence on either pro-survival or pro-death processes in prostate cancer [142]; currently, many studies have been reported to discover natural product with ER stress-mediated anti-cancer activity to develop novel therapeutic agents (Table 5).

Ardisianone (from Ardisia virens Kurz) elevated the level of GRP78/BiP, cytochrome c, AIF, generation of ROS and cleavage of caspases-3,-9 in PC-3 cells, indicating that ER stress and mitochondria-mediated apoptosis were related to ardisianone treatment [143]. Induction of apoptosis in PNT1a and PC3 cells through CHOP expression, triggering BH3-only proteins, AIF and cleavage of caspase-3,-9 was demonstrated by the treatment of Polyphenol E (derived from Camellia sinensis) [144]. Mangosteen Fruit Extract (MFE; derived from Garcinia mangostana) enhanced the level of PERK, CHOP, IRE1 and caspase-4 in both LNCaP and 22Rv1 cells through ER stress, leading to Bax and cleavage of caspase-3 [145]. Upregulation of eIF2 $\alpha$-ATF4-CHOP signaling and caspase-4 in PC-3, DU145, and LNCaP cells through ER stress was observed after treatment of Marchantin M (Mar; derived from Astrella angusta) [146]. Monascuspiloin (derived from Monascus pilosus) treatment facilitated ER stress by activating eIF2 $\alpha$-ATF4-CHOP signaling pathway and caspase-3,-4 in PC-3 cells, which renders PC-3 cells sensitive to ionizing radiation [147]. Quercetin, a ubiquitous polyphenol found in several plants, increased the level of GRP78/BiP, ATF4, IRE1 and caspase-12 in PC-3 cells through ER-stress, which is associated with the induction of $\mathrm{Ca}^{2+}$ and ROS in the cytoplasm. Activation of Bax, cytochrome c, AIF, Endo G, and caspase-3,-9 were also detected [148]. Elevated levels of GRP78/BiP and CHOP in PC-3 cells through ER stress were induced by ZER treatment, resulting in activating cleavage of caspase-3,-7,-9, PARP and Bid along with inhibition of Bcl-2 [149]. 
Table 5. Bioactive compounds from natural products that induce ER stress-mediated apoptosis in prostate cancer.

\begin{tabular}{|c|c|c|c|c|c|}
\hline Family Name & Compound & Cell Line & Duration/Dosage & Mechanism & Reference \\
\hline \multirow{3}{*}{ Ardisia virens Kurz } & \multirow{3}{*}{ Ardisianone } & \multirow{3}{*}{ PC-3 } & \multirow{3}{*}{$10 \mu \mathrm{g} / \mathrm{mL}, 24 \mathrm{~h}$} & GRP78/BiP $\uparrow$ & \multirow{3}{*}{ [143] } \\
\hline & & & & $\begin{array}{l}\text { cleavage ofcaspases-3,-7,-8,-9 } \uparrow \text {, cleavage of PARP } \uparrow, \mathrm{Bcl}-2 \uparrow, \mathrm{Bcl}-\mathrm{xL} \uparrow, \mathrm{Bak} \uparrow, \mathrm{Bax} \uparrow, \\
\text { Bid } \uparrow, \text { PI } 3 \mathrm{~K} / \mathrm{Akt} \downarrow \text {, cytochrome } \mathrm{c} \uparrow, \mathrm{AIF} \uparrow\end{array}$ & \\
\hline & & & & $\operatorname{ROS} \uparrow$ & \\
\hline \multirow{6}{*}{ Camellia sinensis } & \multirow{6}{*}{ Polyphenon E } & \multirow{3}{*}{ PNT1a } & \multirow{3}{*}{$35 \mu \mathrm{g} / \mathrm{mL}, 12 \mathrm{~h}$} & ATF $4 \uparrow$, PERK $\uparrow, \mathrm{p}$-eIF2 $\alpha \uparrow, \mathrm{eIF} 2 \alpha \uparrow, \mathrm{GRP} 78 / \mathrm{BiP} \uparrow, \mathrm{CHOP} \uparrow, \mathrm{XBP} 1 \uparrow$ & \multirow{6}{*}{ [144] } \\
\hline & & & & cleavage of caspase $-3,-7,-9 \uparrow$, Bak $\uparrow$, Puma $\uparrow$, cleavage of PARP $\uparrow$ & \\
\hline & & & & $\operatorname{ROS} \uparrow$ & \\
\hline & & \multirow{3}{*}{ PC3 } & \multirow{3}{*}{$145 \mu \mathrm{g} / \mathrm{mL}, 12 \mathrm{~h}$} & ATF $4 \uparrow$, PERK $\uparrow, \mathrm{p}$-eIF $\alpha \uparrow$, eIF $2 \alpha \uparrow, \mathrm{CHOP} \uparrow, \mathrm{XBP} 1 \uparrow$, & \\
\hline & & & & cleavage of caspase-3,-7,-9 $\uparrow$, Puma $\uparrow$, Bak $\uparrow$, Bax $\uparrow$, PARP $\uparrow$ AIF $\uparrow$ & \\
\hline & & & & $\operatorname{ROS} \uparrow$ & \\
\hline \multirow{4}{*}{ Garcinia mangostana } & \multirow{4}{*}{ Mangosteen Fruit Extract } & \multirow{2}{*}{ LNCaP } & \multirow{2}{*}{$15 \mu \mathrm{g} / \mathrm{mL}, 24 \mathrm{~h}$} & $\begin{array}{l}\text { PERK } \uparrow, I R E 1 \uparrow, \mathrm{CHOP} \uparrow, \mathrm{GRP} 78 / \mathrm{BiP} \uparrow, \text { Ero } 1 \uparrow, \mathrm{ER} \text { chaperone } \uparrow, \mathrm{PDI} \uparrow, \mathrm{XBP} 1 \uparrow, \\
\text { calnexin } \uparrow\end{array}$ & \multirow{4}{*}{ [145] } \\
\hline & & & & Cleavage of caspase- $-3,-4 \uparrow$, Bax $\uparrow$ & \\
\hline & & \multirow[t]{2}{*}{ 22Rv1 cells } & \multirow[t]{2}{*}{$15 \mu \mathrm{g} / \mathrm{mL}, 24 \mathrm{~h}$} & $\begin{array}{l}\text { PERK } \uparrow, \text { IRE1 } \uparrow, \mathrm{CHOP} \uparrow, \mathrm{GRP} 78 / \mathrm{BiP} \uparrow, \mathrm{Ero} 1 \uparrow, \mathrm{ER} \text { chaperone } \uparrow, \mathrm{PDI} \uparrow, \mathrm{XBP} 1 \uparrow, \\
\text { calnexin } \uparrow\end{array}$ & \\
\hline & & & & Cleavage of caspase- $3,-4 \uparrow, \mathrm{Bax} \uparrow$ & \\
\hline \multirow{6}{*}{ Asterella angusta } & \multirow{6}{*}{ Marchantin M } & \multirow{2}{*}{ PC-3 } & \multirow{2}{*}{$10 \mu \mathrm{m}, 48 \mathrm{~h}$} & GRP78 $/ \mathrm{BiP} \uparrow, \mathrm{CHOP} \uparrow, \mathrm{XBP}-1 \uparrow, \mathrm{p}-\mathrm{eIF} 2 \alpha \uparrow, \mathrm{eIF} 2 \alpha \uparrow, \mathrm{ATF} 4 \uparrow, \mathrm{ATF} 6 \uparrow, \mathrm{ERAD} \downarrow$ & \multirow{6}{*}{ [146] } \\
\hline & & & & Cleavage of caspase- $3,-4 \uparrow$ & \\
\hline & & DU145 & $10 \mu \mathrm{M}, 48 \mathrm{~h}$ & GRP78 $/ \mathrm{BiP} \uparrow, \mathrm{CHOP} \uparrow, \mathrm{XBP} 1 \uparrow, \mathrm{p}-\mathrm{eIF} 2 \alpha \uparrow, \mathrm{eIF} 2 \alpha \uparrow, \mathrm{ATF} 4 \uparrow, \mathrm{ATF} 6 \uparrow, \mathrm{ERAD} \downarrow$ & \\
\hline & & & & Cleavage of caspase- $-3,-4 \uparrow$ & \\
\hline & & \multirow{2}{*}{ LNCaP } & \multirow{2}{*}{$10 \mu \mathrm{M}, 48 \mathrm{~h}$} & GRP78 $/ \mathrm{BiP}, \mathrm{CHOP} \uparrow, \mathrm{XBP} 1 \uparrow, \mathrm{p}-\mathrm{eIF} 2 \alpha \uparrow, \mathrm{eIF} 2 \alpha \uparrow, \mathrm{ATF} 4 \uparrow, \mathrm{ATF} 6 \uparrow, \mathrm{ERAD} \downarrow$ & \\
\hline & & & & Cleavage of caspase- $-3,-4 \uparrow$ & \\
\hline \multirow[t]{3}{*}{ Monascus pilosus } & Monascuspiloin & PC-3 & $25 \mu \mathrm{M}, 48 \mathrm{~h}$ & IRE $1 \alpha \uparrow, \mathrm{p}-\mathrm{eIF} 2 \alpha \uparrow, \mathrm{eIF} 2 \alpha \uparrow$ & [147] \\
\hline & \multirow[b]{2}{*}{ Quercetin } & \multirow[b]{2}{*}{ PC-3 } & \multirow[b]{2}{*}{$150 \mu \mathrm{M}, 48 \mathrm{~h}$} & Release of intracellular $\mathrm{Ca}^{2+} \uparrow, \Delta \psi \mathrm{m} \downarrow, \mathrm{GRP} 78 / \mathrm{BiP} \uparrow, \mathrm{ATF} 4 \uparrow, \mathrm{IRE} 1 \alpha \uparrow \mathrm{ATF} 6 \uparrow$ & \multirow[b]{2}{*}{ [148] } \\
\hline & & & & $\begin{array}{l}\text { Bid } \downarrow \text {, Bcl- } 2 \downarrow \text {, cleavage of caspase- } 12 \downarrow \text { Bax } \uparrow, \text { PARP } \uparrow \text {, cytochrome } \mathrm{c} \uparrow, \text { AIF } \uparrow \text {, Endo } \\
\text { G } \uparrow \text {, cleavage of caspase- } 3,-8,-9 \uparrow\end{array}$ & \\
\hline \multirow{2}{*}{ Zingiber zerumbet Smith } & \multirow{2}{*}{ Zerumbone } & \multirow{2}{*}{ PC-3 } & $30 \mu \mathrm{M}, 24 \mathrm{~h}$ & Release of intracellular $\mathrm{Ca}^{2+} \uparrow, \Delta \psi \mathrm{m} \downarrow$, calpain $\uparrow, \mathrm{GRP} 78, \mathrm{CHOP} \uparrow$ & [149] \\
\hline & & & & cleavage of caspase-3,-7,-9 $\uparrow$, cleavage of PARP $\uparrow$, Bid $\uparrow, B c l-2 \downarrow$ & \\
\hline
\end{tabular}

ER associated degradation (ERAD). 


\subsection{Natural Product ER Stress-Mediated Apoptosis in Liver Cancer}

Liver cancer emerged as one of the leading malignancy-related deaths globally. About 7.8 million new cases occurred in 2012, making it the sixth leading malignant neoplasm in the world [3]. Surgery is the main curative treatment for liver cancer, but a majority of patients with liver cancer are diagnosed at advanced stages. Thus chemotherapy has remained the ultimate curative approach for treatment of liver cancer [150]. However, patients tend to suffer from adverse side effect since chemotherapy agents kill both cancer cells and normal cells [151]. ER stress-mediated anti-proliferative effects of natural product have been elucidated through many studies using liver cancer cells [152] (Table 6).

Licochalcone A (derived from Glycyrrhiza inflate) elevated the expression of GRP78/BiP, ATF6, IRE1 $\alpha$, caspase-4, and CHOP in HepG2 cells, leading to cleavage of caspases-3,-9. However, ER stress-mediated apoptosis was inhibited by NAC treatment, indicating ROS involvement in Licochalcone A-induced ER stress [153]. Guggulsterone (originated from Commiphora mukul) increased the levels of GRP78/BiP, PERK, CHOP, JNK, DR5 in Hep3B cells through ER stress. Knockout of CHOP by CHOP siRNA reduced DR5 expression and NAC reverted a suppressive effect of guggulsterone, indicating CHOP-dependent DR5 and ROS-dependent ER-stress by guggulsterone [154]. Enhancement of CHOP-induced DR5 in Hep3B and HepG2 was noted after treatment of verrucarin A (derived from Fungal metabolite) [155]. 7-dimethoxyflavone (DMF; extracted from Myrtacea L. scoparium Forst and Piper methysticum Forst, etc) upregulated the level of ATF4, CHOP, DR5, cleavage of caspase-3,-8,-9 in Hep3B cells. This result suggests that both intrinsic and extrinsic apoptosis pathways are associated with DMF-induced ER stress [156]. GRP78/BiP, PDI, cleavage of caspase-3 and BH-3 family including BIM Bid were upregulated in Hep3B cells by treatment of neferine (isolated from Nelumbo nucifera Gaertn), indicating that ER stress and mitochondria-mediated apoptosis were induced by neferine [157]. Paenol (Pae; derived from Pycnostelma paniculatum K. Schum) elevated the level of GRP78/BiP, CHOP and cleavage of caspase-3 in HepG2 cells. This attenuated ER stress-induced resistance of HepG2 to the therapeutic agent doxorubicin [158]. Expression of elF2 $\alpha, \mathrm{CHOP}, \mathrm{JNK}, \mathrm{MAPK}$ in HepG2 cells were elevated through ER stress following cryptotanshinone treatment. However, NAC treatment down-regulated the apoptotic effect of cryptotanshinone. This result indicates that ER stress-mediated apoptosis via Cryptotanshinone is dependent on ROS generation [117]. 6-Shogaol (extracted from Zingiber officinale Rosc) inhibited SMMC-7721 cells growth via ER stress in terms of PERK-eIF2 $\alpha$-CHOP expression. In addition, oral administration of 6-Shogao suppressed the pro-survival pathway of p-PERK, eIF2a and p-eIF2 $\alpha$ while it increased the cleavage of caspase-3, leading to reduction in SMMC-7721 tumor xenografts model [159]. With the induction of elevated CHOP, caspase-12 expression in Hep3B cells were noted after treatment of genistein (a flavonoid derived from soy products). In addition, activation of Apaf-1, cytochrome c, and cleavage of caspase-3,-9, PARP were observed, indicating mitochondria-mediated apoptosis [160]. 
Table 6. Bioactive compounds from natural products that induce ER stress-mediated apoptosis in liver cancer.

\begin{tabular}{|c|c|c|c|c|c|}
\hline Family Name & Compound & Cell Line & Duration/Dosage & Mechanism & Reference \\
\hline \multirow{3}{*}{ Glycyrrhiza inflate } & \multirow{3}{*}{ Licochalcone A } & \multirow{3}{*}{ HepG2 } & \multirow{3}{*}{$10 \mu \mathrm{M}, 24 \mathrm{~h}$} & $\begin{array}{l}\text { release of intracellular } \mathrm{Ca}^{2+} \uparrow, \Delta \psi \mathrm{m} \downarrow, \mathrm{ATF} 6 \uparrow, \mathrm{eIF} 2 \alpha \uparrow, \mathrm{IRE} 1 \alpha \uparrow, \mathrm{CHOP} \uparrow, \\
\text { GRP94 } \uparrow, \mathrm{XBP} 1 \uparrow, \mathrm{GRP} 78 / \mathrm{BiP} \uparrow\end{array}$ & \multirow{3}{*}{ [153] } \\
\hline & & & & Cleavage of caspases-3,-4,-9 $\uparrow$, cleavage of PARP $\uparrow$ & \\
\hline & & & & $\operatorname{ROS} \uparrow$ & \\
\hline \multirow{10}{*}{ Commiphora mukul } & \multirow{3}{*}{ Guggulsterone } & \multirow{3}{*}{ Нер3В } & \multirow{3}{*}{$30 \mu \mathrm{M}, 12 \mathrm{~h}$} & $\begin{array}{l}\text { Release of intracellular } \mathrm{Ca}^{2+} \uparrow, \Delta \psi \mathrm{m} \downarrow, \mathrm{IRE} 1 \uparrow, \mathrm{JNK} \uparrow, \mathrm{GRP} 78 / \mathrm{BiP}, \mathrm{PERK} \uparrow, \\
\operatorname{eIF} 2 \alpha \uparrow, \mathrm{ATF} 4 \uparrow, \mathrm{CHOP} \uparrow\end{array}$ & \multirow{3}{*}{ [154] } \\
\hline & & & & DR5 $\uparrow$, cleavage of caspase- $3 \uparrow$, cleavage of PARP $\uparrow$ & \\
\hline & & & & $\operatorname{ROS} \uparrow$ & \\
\hline & \multirow{4}{*}{ Verrucarin A } & \multirow[t]{2}{*}{ Нер3В } & \multirow[t]{2}{*}{$1 \mu \mathrm{M}, 12 \mathrm{~h}$} & DR5 $\uparrow$, cleavage of caspase- $3,-8 \uparrow$, cleavage of PARP $\uparrow$ & \multirow{4}{*}{ [155] } \\
\hline & & & & $\operatorname{ROS} \uparrow$ & \\
\hline & & \multirow{2}{*}{ HepG2 } & \multirow{2}{*}{$1 \mu \mathrm{M}, 12 \mathrm{~h}$} & Chop $\uparrow$ & \\
\hline & & & & DR $5 \uparrow$ & \\
\hline & \multirow{3}{*}{ 7-dimethoxyflavone } & \multirow{3}{*}{ Нер3В } & \multirow{3}{*}{$5 \mu \mathrm{mol}, 24 \mathrm{~h}$} & $\mathrm{CHOP} \uparrow, \mathrm{GPR} 78 / \mathrm{BiP} \uparrow, \mathrm{ATF} 4 \uparrow$ & \multirow{3}{*}{ [156] } \\
\hline & & & & DR5 $\uparrow$, cleavage of caspase-3,-8,-9 $\uparrow$ & \\
\hline & & & & $\operatorname{ROS} \uparrow$ & \\
\hline Nelumbo nucifera Gaertn & Neferine & Нер3В & $20 \mu \mathrm{mol}, 24 \mathrm{~h}$ & GRP78/BiP $\uparrow$, calnexin $\uparrow$, PDI $\uparrow$, calpain $\uparrow$ & [157] \\
\hline \multirow{2}{*}{$\begin{array}{l}\text { Pycnostelma paniculatum } \mathrm{K} \\
\text { Schum }\end{array}$} & \multirow{2}{*}{ Paeonol } & \multirow{2}{*}{ HepG2 } & \multirow{2}{*}{$31.25 \mathrm{mg} / \mathrm{mL}, 24 \mathrm{~h}$} & GRP78 $\uparrow, \mathrm{CHOP} \uparrow$ & \multirow{2}{*}{ [158] } \\
\hline & & & & cleavage of caspase- $3 \uparrow$, PI3K $/$ AKT $\downarrow$ & \\
\hline \multirow{3}{*}{ Salvia miltiorrhiza Bunge } & \multirow{3}{*}{ Cryptotanshinone } & & & eIF2 $\alpha \uparrow$, GRP9 $4 \uparrow$, GRP78 $/ \mathrm{BiP} \uparrow$, cisplatin $\uparrow, \mathrm{CHOP} \uparrow$ & \\
\hline & & HepG2 & $10 \mu \mathrm{M}, 24 \mathrm{~h}$ & cleavage of PARP $\uparrow, \mathrm{JNK} \uparrow, \mathrm{MAPK} \uparrow$ & [117] \\
\hline & & & & $\operatorname{ROS} \uparrow$ & \\
\hline & & SMMC-7721 & $20 \mu \mathrm{M}, 6 \mathrm{~h}$ & GRP94 $\uparrow$, GRP78 $/ \mathrm{BiP} \uparrow, \mathrm{CHOP} \uparrow, \mathrm{p}-\mathrm{PERK} \uparrow, \mathrm{PERK} \uparrow, \mathrm{eIF} 2 \alpha \uparrow, \mathrm{p}$-eIF2 $\alpha \uparrow$ & \\
\hline Zingiber officinale Rosc & 6-Shogaol & & & cleavage of PARP $\uparrow$, cleavage of caspase- $3 \uparrow$ & [159] \\
\hline & & SMMC-7721 xenograft in & 6-shogaol (orally, 10 & p-PERK $\downarrow$, eIF $2 \alpha \downarrow$, p-eIF2 $\alpha \downarrow$ & \\
\hline & & Male SCID mice & $\mathrm{mg} / \mathrm{kg}), 28$ days & cleavage of caspase- $3 \uparrow$ & \\
\hline & & & & release of intracellular $\mathrm{Ca}^{2+} \uparrow, \Delta \psi \mathrm{m} \downarrow$, calpain $\uparrow, \mathrm{CHOP} \uparrow, \mathrm{GRP} 78 / \mathrm{BiP} \uparrow$ & \\
\hline & Genistein & Нер3В & $100 \mu \mathrm{M}, 48 \mathrm{~h}$ & $\begin{array}{l}\text { cleavage of caspase- } 2,-3,-7,-12 \uparrow \text {, cleavage of PARP } \uparrow, \text { Apaf- } 1 \uparrow \text { cytochrome } c \uparrow \text {, } \\
\text { Bad } \uparrow\end{array}$ & [160] \\
\hline & & & & $\operatorname{ROS} \uparrow$ & \\
\hline
\end{tabular}




\section{Discussion}

Cancer remains one of the leading causes of death in the world today. Although significant medical and technological developments have been achieved, still conventional cancer-targeted therapies have severe side effects and complications such as serious toxicities and development of resistance [161,162]. Therefore, one of the major goals for cancer treatment is to find novel therapeutic approaches which make it possible to selectively kill cancer cells without harming normal cells and reduce cancer cellular resistance to chemotherapeutic agents [145,147,158,163].

Upon quick expansion of the cancer tumor-microenvironment such as hypoxia, lack of glucose may have an impact on protein folding in ER of cancer cells, resulting in the accumulation of unfolded proteins, termed ER stress [22]. To overcome the hostile environment, UPR is initiated in cancer cells to attenuate ER stress for cancer survival. In fact, proteins related to UPR such as GRP78/BiP, XBP1, IRE1 were reported to be promoted in ischemic regions of cancer [17]. Also, activation of GPR78/BiP, XBP1 and ATF6 were observed in hepatocellular carcinoma cell line compared to non-cancerous liver tissues [164]. In addition, ER stress response may generate drug resistance as a survival response via activation of UPR [165]. For example, induction of the UPR in multiple myeloma cells enhanced resistance to etoposide [166]. These indicate that ER stress response may act as a key driver in tumorigenesis and the development of resistance to chemotherapy [43]. However, if the ER stress persists, apoptosis is induced in cancer cells [167]. These related findings provide clues that targeting the ER stress response, either inhibiting adaptive function or stimulating apoptotic function, may be an effective strategy for more selective cancer therapy and overcoming drug resistance [147].

As a way of cancer treatment, natural product-derived compounds are being introduced to the medical research and conducted to test the efficacy against cancers [168,169]. Especially, researches focusing on the cross link between the natural product or its derived compound and apoptosis in cancer via ER stress, are gaining interest [170,171]. Natural products or their bioactive compounds not only trigger apoptosis but also lower the resistance to chemotherapies via modulating ER stress. For example, brefeldin A derived from Eupenicillium brefeldianum was proven as an ER stress-inducing agent to overcome one of the standard drugs for leukemia fludarabine [172]. Also, Pae, which is derived from Pycnostelma paniculatum K. Schum, lowers the resistance of doxorubicin [158]. Furthermore, natural compounds were demonstrated to induce a synergistic effect with current standard therapies through ER stress regulation. For instance, Epigallocatechin 3-gallate, a polyphenolic green tea component, increased the apoptotic activity of temozolomide in glioblastoma cell death through inhibition of GPR78/BiP [173]. And falcarindiol, a natural polyyne in dietary plants, was identified to induce a synergistic effect with 5-Fluorouracil and bortezomib on suppressing breast cancer via upregulation of CHOP [174].

This present review summarizes the mechanisms of ER stress and its role in cancer development as well as apoptosis. It also delineates two approaches targeting the UPR as an anticancer strategy [19]: To inhibit ER stress-related proteins, to render cancer growing under stressful conditions to no longer be able to deal with the stress [11], and to induce chronic stress on cancer cells thereby tipping the balance towards cell death. Furthermore, the up-to-date researches were highlighted which were done with natural products in relation to the ER stress-mediated apoptosis in six types of leading cancers world-wide: lung, breast, colorectal, gastric, prostate cancer, and liver cancer, referring to the World Cancer Report 2014 by International Agency for Research on Cancer [2,3]. The related studies in this topic will not only significantly clarify our understanding of ER stress in cancer biology but also advance knowledge of interplay between natural product and ER stress-mediated apoptosis against cancer. Although cumulative evidences demonstrate that targeting ER stress as an anti-cancer strategy seems very promising. Further studies for the exact roles of ER stress in cancer and how they act on cell fate need to be investigated. Increasing knowledge in this area will be essential for pharmaceutical design toward controlling cancer through modulating UPR signaling [20,33]. Moreover, further research into ER stress could be utilized for other medical applications including the 
prognosis and diagnosis of multiple cancer types and could also be a solution to its involvement in chemo-resistance [26,35].

However, to successfully convert a potent natural product-derived compound to a clinically viable drug, several following questions needs to be addressed: (i) Do natural products exert selective cytotoxicity on cancer cells not on normal cells? (ii) Is it effective to target the ER stress as an anti-cancer strategy against other types of cancers? (iii) Do natural products or their derived compounds possess any special effects compared to those often seen with conventional drugs for cancer treatment? (iv) How might natural products cooperate with therapeutic agents that cause cancer cellular stress? (v) Can natural products or their derivatives induce a synergistic effect with conventional cancer treatment or unexpected side effects? Furthermore, since natural products or their molecular approaches targeting ER stress in cancer treatment are only in the early stage of research, most of the studies have focused on in vitro. Hence, additional investigation into pharmacokinetics with animal models and clinical studies are necessary. In addition, proper dosage of natural product needs to be considered to prevent the potential toxicity produced by natural products when developing natural product-derived compounds into clinically viable drugs [175]. For instance, ZER, which induces ER stress-mediated apoptosis in prostate cancer, was demonstrated to cause nephrocellular and hepatocellular damage by single intraperitoneal injection of $500 \mathrm{mg} / \mathrm{kg}$ ZER in sprague dawley (SD) rats [176]. Polyphenon E, which suppresses prostate cancer growth through ER stress, was identified to induce the mutant frequency in thymidine kinase locus and damage the myocardial fiber of Big Blue transgenic mouse when administered at a dosage of $2000 \mathrm{mg} / \mathrm{kg}$ for 28 days [177].

Eventually, more researches in this area will make clear understanding about the underlying mechanism of cross link between natural products and ER mediated-apoptosis. Also, enhanced knowledge in this area can be impetus for future developments of novel medicine not only in cancer treatment but also other diseases known to be associated with ER stress such as cardiovascular, inflammatory, and neurological diseases [178,179]. Importantly, additional evaluation of the therapeutic effects of natural products on cancer would provide us with an effective strategy to potentiate the health benefits of natural products.

Author Contributions: C.K. collected the data and C.K. and B.K. wrote and revised the manuscript.

Funding: This Research was supported by the Basic Science Research Program through the National Research Foundation of Korea (NRF) funded by the Ministry of Education (NRF-2016R1D1A1B03933656).

Conflicts of Interest: The authors declare that the research was conducted in the absence of any commercial or financial relationships that could be construed as a potential conflict of interest.

\section{References}

1. Hsu, P.P.; Sabatini, D.M. Cancer cell metabolism: Warburg and beyond. Cell 2008, 134, 703-707. [CrossRef] [PubMed]

2. Stewart, B.W.; Wild, C.P. World Cancer Report 2014; World Health Organization: Lyon, France, 2016.

3. Ferlay, J.; Soerjomataram, I.; Dikshit, R.; Eser, S.; Mathers, C.; Rebelo, M.; Parkin, D.M.; Forman, D.; Bray, F. Cancer incidence and mortality worldwide: Sources, methods and major patterns in globocan 2012. Int. J. Cancer 2015, 136, E359-E386. [CrossRef] [PubMed]

4. Reed, J.C. Dysregulation of apoptosis in cancer. J. Clin. Oncol. 1999, 17, 2941-2953. [CrossRef] [PubMed]

5. Fisher, D.E. Apoptosis in cancer therapy: Crossing the threshold. Cell 1994, 78, 539-542. [CrossRef]

6. Brown, J.M.; Attardi, L.D. The role of apoptosis in cancer development and treatment response. Nat. Rev. Cancer 2005, 5, 231-237. [CrossRef] [PubMed]

7. Ghobrial, I.M.; Witzig, T.E.; Adjei, A.A. Targeting apoptosis pathways in cancer therapy. CA Cancer J. Clin. 2005, 55, 178-194. [CrossRef] [PubMed]

8. Fulda, S.; Debatin, K.-M. Extrinsic versus intrinsic apoptosis pathways in anticancer chemotherapy. Oncogene 2006, 25, 4798-4811. [CrossRef] [PubMed]

9. Debatin, K.-M. Apoptosis pathways in cancer and cancer therapy. Cancer Immunol. Immunother. 2004, 53, 153-159. [CrossRef] [PubMed] 
10. Kim, I.; Xu, W.; Reed, J.C. Cell death and endoplasmic reticulum stress: Disease relevance and therapeutic opportunities. Nat. Rev. Drug Discov. 2008, 7, 1013-1030. [CrossRef] [PubMed]

11. Schröder, M.; Kaufman, R.J. The mammalian unfolded protein response. Annu. Rev. Biochem. 2005, 74, 739-789. [CrossRef] [PubMed]

12. Kaufman, R.J. Orchestrating the unfolded protein response in health and disease. J. Clin. Investig. 2002, 110, 1389-1398. [CrossRef] [PubMed]

13. Hebert, D.N.; Molinari, M. In and out of the ER: Protein folding, quality control, degradation, and related human diseases. Physiol. Rev. 2007, 87, 1377-1408. [CrossRef] [PubMed]

14. Yadav, R.K.; Chae, S.-W.; Kim, H.-R.; Chae, H.J. Endoplasmic reticulum stress and cancer. J. Cancer Prev. 2014, 19, 75-88. [CrossRef] [PubMed]

15. Romero-Ramirez, L.; Cao, H.; Nelson, D.; Hammond, E.; Lee, A.-H.; Yoshida, H.; Mori, K.; Glimcher, L.H.; Denko, N.C.; Giaccia, A.J. XBP1 is essential for survival under hypoxic conditions and is required for tumor growth. Cancer Res. 2004, 64, 5943-5947. [CrossRef] [PubMed]

16. Jamora, C.; Dennert, G.; Lee, A.S. Inhibition of tumor progression by suppression of stress protein GRP78/BIP induction in fibrosarcoma B/C10ME. Proc. Natl. Acad. Sci. USA 1996, 93, 7690-7694. [CrossRef] [PubMed]

17. Bi, M.; Naczki, C.; Koritzinsky, M.; Fels, D.; Blais, J.; Hu, N.; Harding, H.; Novoa, I.; Varia, M.; Raleigh, J. ER stress-regulated translation increases tolerance to extreme hypoxia and promotes tumor growth. EMBO J. 2005, 24, 3470-3481. [CrossRef] [PubMed]

18. Wang, M.; Kaufman, R.J. The impact of the endoplasmic reticulum protein-folding environment on cancer development. Nat. Rev. Cancer 2014, 14, 581-597. [CrossRef] [PubMed]

19. Urra, H.; Dufey, E.; Lisbona, F.; Rojas-Rivera, D.; Hetz, C. When ER stress reaches a dead end. Biochim. Biophys. Acta (BBA)-Mol. Cell Res. 2013, 1833, 3507-3517. [CrossRef] [PubMed]

20. Wang, G.; Yang, Z.-Q.; Zhang, K. Endoplasmic reticulum stress response in cancer: Molecular mechanism and therapeutic potential. Am. J. Transl. Res. 2010, 2, 65-74. [PubMed]

21. Sui, X.; Chen, R.; Wang, Z.; Huang, Z.; Kong, N.; Zhang, M.; Han, W.; Lou, F.; Yang, J.; Zhang, Q. Autophagy and chemotherapy resistance: A promising therapeutic target for cancer treatment. Cell Death Dis. 2013, 4, e838. [CrossRef] [PubMed]

22. Martinon, F. Targeting endoplasmic reticulum signaling pathways in cancer. Acta Oncol. 2012, 51, 822-830. [CrossRef] [PubMed]

23. Schindler, A.J.; Schekman, R. In vitro reconstitution of er-stress induced atf6 transport in copii vesicles. Proc. Natl. Acad. Sci. USA 2009, 106, 17775-17780. [CrossRef] [PubMed]

24. Yoshida, H.; Okada, T.; Haze, K.; Yanagi, H.; Yura, T.; Negishi, M.; Mori, K. ATF6 activated by proteolysis binds in the presence of NF-Y (CBF) directly to the cis-acting element responsible for the mammalian unfolded protein response. Mol. Cell. Biol. 2000, 20, 6755-6767. [CrossRef] [PubMed]

25. Wu, J.; Rutkowski, D.T.; Dubois, M.; Swathirajan, J.; Saunders, T.; Wang, J.; Song, B.; Yau, G.D.-Y.; Kaufman, R.J. ATF6A optimizes long-term endoplasmic reticulum function to protect cells from chronic stress. Dev. Cell 2007, 13, 351-364. [CrossRef] [PubMed]

26. Lee, A.S. GRP78 induction in cancer: Therapeutic and prognostic implications. Cancer Res. 2007, 67, 3496-3499. [CrossRef] [PubMed]

27. Scriven, P.; Coulson, S.; Haines, R.; Balasubramanian, S.; Cross, S.; Wyld, L. Activation and clinical significance of the unfolded protein response in breast cancer. Br. J. Cancer 2009, 101, 1692-1698. [CrossRef] [PubMed]

28. Uramoto, H.; Sugio, K.; Oyama, T.; Nakata, S.; Ono, K.; Yoshimastu, T.; Morita, M.; Yasumoto, K. Expression of endoplasmic reticulum molecular chaperone GRP78 in human lung cancer and its clinical significance. Lung Cancer 2005, 49, 55-62. [CrossRef] [PubMed]

29. Zhang, J.; Jiang, Y.; Jia, Z.; Li, Q.; Gong, W.; Wang, L.; Wei, D.; Yao, J.; Fang, S.; Xie, K. Association of elevated GRP78 expression with increased lymph node metastasis and poor prognosis in patients with gastric cancer. Clin. Exp. Metast. 2006, 23, 401-410. [CrossRef] [PubMed]

30. Daneshmand, S.; Quek, M.L.; Lin, E.; Lee, C.; Cote, R.J.; Hawes, D.; Cai, J.; Groshen, S.; Lieskovsky, G.; Skinner, D.G. Glucose-regulated protein GRP78 is up-regulated in prostate cancer and correlates with recurrence and survival. Hum. Pathol. 2007, 38, 1547-1552. [CrossRef] [PubMed]

31. Lee, E.; Nichols, P.; Spicer, D.; Groshen, S.; Mimi, C.Y.; Lee, A.S. GRP78 as a novel predictor of responsiveness to chemotherapy in breast cancer. Cancer Res. 2006, 66, 7849-7853. [CrossRef] [PubMed] 
32. Abcouwer, S.F.; Marjon, P.L.; Loper, R.K.; Vander Jagt, D.L. Response of VEGF expression to amino acid deprivation and inducers of endoplasmic reticulum stress. Investig. Ophthalmol. Vis. Sci. 2002, 43, 2791-2798.

33. Backer, J.M.; Krivoshein, A.V.; Hamby, C.V.; Pizzonia, J.; Gilbert, K.S.; Ray, Y.S.; Brand, H.; Paton, A.W.; Paton, J.C.; Backer, M.V. Chaperone-targeting cytotoxin and endoplasmic reticulum stress-inducing drug synergize to kill cancer cells. Neoplasia 2009, 11, 1165-1173. [CrossRef] [PubMed]

34. Pyrko, P.; Schönthal, A.H.; Hofman, F.M.; Chen, T.C.; Lee, A.S. The unfolded protein response regulator GRP78/BiP as a novel target for increasing chemosensitivity in malignant gliomas. Cancer Res. 2007, 67, 9809-9816. [CrossRef] [PubMed]

35. Firczuk, M.; Gabrysiak, M.; Barankiewicz, J.; Domagala, A.; Nowis, D.; Kujawa, M.; Jankowska-Steifer, E.; Wachowska, M.; Glodkowska-Mrowka, E.; Korsak, B. GRP78-targeting subtilase cytotoxin sensitizes cancer cells to photodynamic therapy. Cell Death Dis. 2013, 4, e741. [CrossRef] [PubMed]

36. Wey, S.; Luo, B.; Tseng, C.-C.; Ni, M.; Zhou, H.; Fu, Y.; Bhojwani, D.; Carroll, W.L.; Lee, A.S. Inducible knockout of GRP78/BiP in the hematopoietic system suppresses pten-null leukemogenesis and AKT oncogenic signaling. Blood 2012, 119, 817-825. [CrossRef] [PubMed]

37. Saito, S.; Furuno, A.; Sakurai, J.; Sakamoto, A.; Park, H.-R.; Shin-ya, K.; Tsuruo, T.; Tomida, A. Chemical genomics identifies the unfolded protein response as a target for selective cancer cell killing during glucose deprivation. Cancer Res. 2009, 69, 4225-4234. [CrossRef] [PubMed]

38. Fu, Y.; Wey, S.; Wang, M.; Ye, R.; Liao, C.-P.; Roy-Burman, P.; Lee, A.S. Pten null prostate tumorigenesis and AKT activation are blocked by targeted knockout of er chaperone GRP78/BiP in prostate epithelium. Proc. Natl. Acad. Sci. USA 2008, 105, 19444-19449. [CrossRef] [PubMed]

39. Wang, X.Z.; Harding, H.P.; Zhang, Y.; Jolicoeur, E.M.; Kuroda, M.; Ron, D. Cloning of mammalian Ire1 reveals diversity in the ER stress responses. EMBO J. 1998, 17, 5708-5717. [CrossRef] [PubMed]

40. Tirasophon, W.; Welihinda, A.A.; Kaufman, R.J. A stress response pathway from the endoplasmic reticulum to the nucleus requires a novel bifunctional protein kinase/endoribonuclease (IRE1P) in mammalian cells. Genes Dev. 1998, 12, 1812-1824. [CrossRef] [PubMed]

41. Liu, Y.; Adachi, M.; Zhao, S.; Hareyama, M.; Koong, A.; Luo, D.; Rando, T.; Imai, K.; Shinomura, Y. Preventing oxidative stress: A new role for XBP1. Cell Death Differ. 2009, 16, 847-857. [CrossRef] [PubMed]

42. Lee, A.-H.; Iwakoshi, N.N.; Glimcher, L.H. XBP-1 regulates a subset of endoplasmic reticulum resident chaperone genes in the unfolded protein response. Mol. Cell. Biol. 2003, 23, 7448-7459. [CrossRef] [PubMed]

43. Koong, A.C.; Chauhan, V.; Romero-Ramirez, L. Targeting XBP-1 as a novel anti-cancer strategy. Cancer Biol. Ther. 2006, 5, 756-759. [CrossRef] [PubMed]

44. Chen, Y.; Feldman, D.E.; Deng, C.; Brown, J.A.; De Giacomo, A.F.; Gaw, A.F.; Shi, G.; Le, Q.T.; Brown, J.M.; Koong, A.C. Identification of mitogen-activated protein kinase signaling pathways that confer resistance to endoplasmic reticulum stress in saccharomyces cerevisiae. Mol. Cancer Res. 2005, 3, 669-677. [CrossRef] [PubMed]

45. Romero-Ramirez, L.; Cao, H.; Regalado, M.P.; Kambham, N.; Siemann, D.; Kim, J.J.; Le, Q.T.; Koong, A.C. X box-binding protein 1 regulates angiogenesis in human pancreatic adenocarcinomas. Transl. Oncol. 2009, 2, 31-38. [CrossRef] [PubMed]

46. Acosta-Alvear, D.; Zhou, Y.; Blais, A.; Tsikitis, M.; Lents, N.H.; Arias, C.; Lennon, C.J.; Kluger, Y.; Dynlacht, B.D. XBP1 controls diverse cell type-and condition-specific transcriptional regulatory networks. Mol. Cell 2007, 27, 53-66. [CrossRef] [PubMed]

47. Liu, Y.; Zhang, X.; Liang, Y.; Yu, H.; Chen, X.; Zheng, T.; Zheng, B.; Wang, L.; Zhao, L.; Shi, C. Targeting $\mathrm{x}$ box-binding protein-1 (XBP1) enhances sensitivity of glioma cells to oxidative stress. Neuropathol. Appl. Neurobiol. 2011, 37, 395-405. [CrossRef] [PubMed]

48. Papandreou, I.; Denko, N.C.; Olson, M.; Van Melckebeke, H.; Lust, S.; Tam, A.; Solow-Cordero, D.E.; Bouley, D.M.; Offner, F.; Niwa, M. Identification of an ire1alpha endonuclease specific inhibitor with cytotoxic activity against human multiple myeloma. Blood 2011, 117, 1311-1314. [CrossRef] [PubMed]

49. Marciniak, S.J.; Garcia-Bonilla, L.; Hu, J.; Harding, H.P.; Ron, D. Activation-dependent substrate recruitment by the eukaryotic translation initiation factor 2 kinase perk. J Cell Biol. 2006, 172, 201-209. [CrossRef] [PubMed]

50. DuRose, J.B.; Scheuner, D.; Kaufman, R.J.; Rothblum, L.I.; Niwa, M. Phosphorylation of eukaryotic translation initiation factor $2 \alpha$ coordinates rrna transcription and translation inhibition during endoplasmic reticulum stress. Mol. Cell. Biol. 2009, 29, 4295-4307. [CrossRef] [PubMed] 
51. Shi, Y.; Vattem, K.M.; Sood, R.; An, J.; Liang, J.; Stramm, L.; Wek, R.C. Identification and characterization of pancreatic eukaryotic initiation factor $2 \alpha$-subunit kinase, PEK, involved in translational control. Mol. Cell. Biol. 1998, 18, 7499-7509. [CrossRef] [PubMed]

52. Harding, H.P.; Zhang, Y.; Zeng, H.; Novoa, I.; Lu, P.D.; Calfon, M.; Sadri, N.; Yun, C.; Popko, B.; Paules, R. An integrated stress response regulates amino acid metabolism and resistance to oxidative stress. Mol. Cell 2003, 11, 619-633. [CrossRef]

53. Verfaillie, T.; Garg, A.D.; Agostinis, P. Targeting er stress induced apoptosis and inflammation in cancer. Cancer Lett. 2013, 332, 249-264. [CrossRef] [PubMed]

54. Harding, H.P.; Zhang, Y.; Bertolotti, A.; Zeng, H.; Ron, D. Perk is essential for translational regulation and cell survival during the unfolded protein response. Mol. Cell 2000, 5, 897-904. [CrossRef]

55. Rouschop, K.M.; Dubois, L.J.; Keulers, T.G.; van den Beucken, T.; Lambin, P.; Bussink, J.; van der Kogel, A.J.; Koritzinsky, M.; Wouters, B.G. PERK/eIF2 $\alpha$ signaling protects therapy resistant hypoxic cells through induction of glutathione synthesis and protection against ros. Proc. Natl. Acad. Sci. USA 2013, 110, 4622-4627. [CrossRef] [PubMed]

56. Koumenis, C.; Naczki, C.; Koritzinsky, M.; Rastani, S.; Diehl, A.; Sonenberg, N.; Koromilas, A.; Wouters, B.G. Regulation of protein synthesis by hypoxia via activation of the endoplasmic reticulum kinase perk and phosphorylation of the translation initiation factor eIF2 $\alpha$. Mol. Cell. Biol. 2002, 22, 7405-7416. [CrossRef] [PubMed]

57. Blais, J.D.; Addison, C.L.; Edge, R.; Falls, T.; Zhao, H.; Wary, K.; Koumenis, C.; Harding, H.P.; Ron, D.; Holcik, M. Perk-dependent translational regulation promotes tumor cell adaptation and angiogenesis in response to hypoxic stress. Mol. Cell. Biol. 2006, 26, 9517-9532. [CrossRef] [PubMed]

58. Ferri, K.F.; Kroemer, G. Organelle-specific initiation of cell death pathways. Nat. Cell Biol. 2001, 3, E255-E263. [CrossRef] [PubMed]

59. Tabas, I.; Ron, D. Integrating the mechanisms of apoptosis induced by endoplasmic reticulum stress. Nat. Cell Biol. 2011, 13, 184. [CrossRef] [PubMed]

60. Cullinan, S.B.; Diehl, J.A. Coordination of er and oxidative stress signaling: The PERK/Nrf2 signaling pathway. Int. J. Biochem. Cell Biol. 2006, 38, 317-332. [CrossRef] [PubMed]

61. Liu, Z.-W.; Zhu, H.-T.; Chen, K.-L.; Dong, X.; Wei, J.; Qiu, C.; Xue, J.-H. Protein kinase RNA-like endoplasmic reticulum kinase (PERK) signaling pathway plays a major role in reactive oxygen species (ROS)-mediated endoplasmic reticulum stress-induced apoptosis in diabetic cardiomyopathy. Cardiovasc. Diabetol. 2013, 12, 158. [CrossRef] [PubMed]

62. Yokouchi, M.; Hiramatsu, N.; Hayakawa, K.; Okamura, M.; Du, S.; Kasai, A.; Takano, Y.; Shitamura, A.; Shimada, T.; Yao, J. Involvement of selective reactive oxygen species upstream of proapoptotic branches of unfolded protein response. J. Biol. Chem. 2008, 283, 4252-4260. [CrossRef] [PubMed]

63. Oyadomari, S.; Mori, M. Roles of CHOP/GADD153 in endoplasmic reticulum stress. Cell Death Differ. 2004, 11, 381-389. [CrossRef] [PubMed]

64. Novoa, I.; Zeng, H.; Harding, H.P.; Ron, D. Feedback inhibition of the unfolded protein response by GADD34-mediated dephosphorylation of eIF2 $\alpha$. J. Cell Biol. 2001, 153, 1011-1022. [CrossRef] [PubMed]

65. Li, G.; Mongillo, M.; Chin, K.-T.; Harding, H.; Ron, D.; Marks, A.R.; Tabas, I. Role of ero1- $\alpha$-mediated stimulation of inositol 1, 4, 5-triphosphate receptor activity in endoplasmic reticulum stress-induced apoptosis. J. Cell Biol. 2009, 186, 783-792. [CrossRef] [PubMed]

66. Ozcan, L.; Tabas, I. Pivotal Role of Calcium/Calmodulin-Dependent Protein Kinase II in ER Stress-Induced Apoptosis. Cell cycle 2010, 9, 223-224. [CrossRef] [PubMed]

67. Yamaguchi, H.; Wang, H.-G. Chop is involved in endoplasmic reticulum stress-induced apoptosis by enhancing DR5 expression in human carcinoma cells. J. Biol. Chem. 2004, 279, 45495-45502. [CrossRef] [PubMed]

68. Li, H.; Zhu, H.; Xu, C.-J.; Yuan, J. Cleavage of bid by caspase 8 mediates the mitochondrial damage in the fas pathway of apoptosis. Cell 1998, 94, 491-501. [CrossRef]

69. Puthalakath, H.; O’Reilly, L.A.; Gunn, P.; Lee, L.; Kelly, P.N.; Huntington, N.D.; Hughes, P.D.; Michalak, E.M.; McKimm-Breschkin, J.; Motoyama, N. ER stress triggers apoptosis by activating BH3-only protein Bim. Cell 2007, 129, 1337-1349. [CrossRef] [PubMed]

70. Reimertz, C.; Kögel, D.; Rami, A.; Chittenden, T.; Prehn, J.H. Gene expression during ER stress-induced apoptosis in neurons: Induction of the BH3-only protein Bbc3/PUMA and activation of the mitochondrial apoptosis pathway. J.Cell Biol. 2003, 162, 587-597. [CrossRef] [PubMed] 
71. Huber, A.-L.; Lebeau, J.; Guillaumot, P.; Pétrilli, V.; Malek, M.; Chilloux, J.; Fauvet, F.; Payen, L.; Kfoury, A.; Renno, T. P58 IPK-mediated attenuation of the proapoptotic perk-chop pathway allows malignant progression upon low glucose. Mol. Cell 2013, 49, 1049-1059. [CrossRef] [PubMed]

72. Nakagawa, H.; Umemura, A.; Taniguchi, K.; Font-Burgada, J.; Dhar, D.; Ogata, H.; Zhong, Z.; Valasek, M.A.; Seki, E.; Hidalgo, J. ER stress cooperates with hypernutrition to trigger TNF-dependent spontaneous hcc development. Cancer Cell 2014, 26, 331-343. [CrossRef] [PubMed]

73. Matsukawa, J.; Matsuzawa, A.; Takeda, K.; Ichijo, H. The ASK1-MAP kinase cascades in mammalian stress response. J. Biochem. 2004, 136, 261-265. [CrossRef] [PubMed]

74. Fischer, H.; Koenig, U.; Eckhart, L.; Tschachler, E. Human caspase 12 has acquired deleterious mutations. Biochem. Biophy. Res. Commun. 2002, 293, 722-726. [CrossRef]

75. Dhanasekaran, D.N.; Reddy, E.P. JNK signaling in apoptosis. Oncogene 2008, 27, 6245. [CrossRef] [PubMed]

76. Yoneda, T.; Imaizumi, K.; Oono, K.; Yui, D.; Gomi, F.; Katayama, T.; Tohyama, M. Activation of caspase-12, an endoplastic reticulum (ER) resident caspase, through tumor necrosis factor receptor-associated factor 2-dependent mechanism in response to the er stress. J. Biol. Chem. 2001, 276, 13935-13940. [CrossRef] [PubMed]

77. Nishitoh, H.; Matsuzawa, A.; Tobiume, K.; Saegusa, K.; Takeda, K.; Inoue, K.; Hori, S.; Kakizuka, A.; Ichijo, H. ASK1 is essential for endoplasmic reticulum stress-induced neuronal cell death triggered by expanded polyglutamine repeats. Genes Dev. 2002, 16, 1345-1355. [CrossRef] [PubMed]

78. Harris, C.A.; Johnson, E.M. BH3-only Bcl-2 family members are coordinately regulated by the JNK pathway and require Bax to induce apoptosis in neurons. J. Biol. Chem. 2001, 276, 37754-37760. [PubMed]

79. Yu, C.; Minemoto, Y.; Zhang, J.; Liu, J.; Tang, F.; Bui, T.N.; Xiang, J.; Lin, A. JNK suppresses apoptosis via phosphorylation of the proapoptotic Bcl-2 family protein bad. Mol. Cell 2004, 13, 329-340. [CrossRef]

80. Urano, F.; Wang, X.; Bertolotti, A.; Zhang, Y.; Chung, P.; Harding, H.P.; Ron, D. Coupling of stress in the ER to activation of JNK protein kinases by transmembrane protein kinase IRE1. Science 2000, 287, 664-666. [CrossRef] [PubMed]

81. Li, J.; Ni, M.; Lee, B.; Barron, E.; Hinton, D.; Lee, A. The unfolded protein response regulator GRP78/BiP is required for endoplasmic reticulum integrity and stress-induced autophagy in mammalian cells. Cell Death Differ. 2008, 15, 1460-1471. [CrossRef] [PubMed]

82. Wang, Y.; Guo, S.-H.; Shang, X.-J.; Yu, L.-S.; Zhu, J.-W.; Zhao, A.; Zhou, Y.-F.; An, G.-H.; Zhang, Q.; Ma, B. Triptolide induces sertoli cell apoptosis in mice via ROS/JNK-dependent activation of the mitochondrial pathway and inhibition of Nrf2-mediated antioxidant response. Acta Pharmacol. Sin. 2018, 39, 311-327. [CrossRef] [PubMed]

83. Zhang, Y.; Chen, F. Reactive oxygen species (ROS), troublemakers between nuclear factor-kb (NF-kb) and c-Jun $\mathrm{NH}_{2}$-terminal kinase (JNK). Cancer Res. 2004, 64, 1902-1905. [CrossRef] [PubMed]

84. Kowaltowski, A.J.; Naia-da-Silva, E.S.; Castilho, R.F.; Vercesi, A.E. Ca ${ }^{2+}$-stimulated mitochondrial reactive oxygen species generation and permeability transition are inhibited by dibucaine or $\mathrm{Mg}^{2+}$. Arch. Biochem. Biophys. 1998, 359, 77-81. [CrossRef] [PubMed]

85. Tan, Y.; Dourdin, N.; Wu, C.; De Veyra, T.; Elce, J.S.; Greer, P.A. Ubiquitous calpains promote caspase-12 and JNK activation during endoplasmic reticulum stress-induced apoptosis. J. Biol. Chem. 2006, 281, 16016-16024. [CrossRef] [PubMed]

86. Duchen, M.R. Contributions of mitochondria to animal physiology: From homeostatic sensor to calcium signalling and cell death. J. Physiol. 1999, 516, 1-17. [CrossRef] [PubMed]

87. Kuwana, T.; Bouchier-Hayes, L.; Chipuk, J.E.; Bonzon, C.; Sullivan, B.A.; Green, D.R.; Newmeyer, D.D. $\mathrm{BH} 3$ domains of BH3-only proteins differentially regulate Bax-mediated mitochondrial membrane permeabilization both directly and indirectly. Mol. Cell 2005, 17, 525-535. [CrossRef] [PubMed]

88. Hao, Z.; Duncan, G.S.; Chang, C.-C.; Elia, A.; Fang, M.; Wakeham, A.; Okada, H.; Calzascia, T.; Jang, Y.; You-Ten, A. Specific ablation of the apoptotic functions of cytochrome $\mathrm{C}$ reveals a differential requirement for cytochrome C and Apaf-1 in apoptosis. Cell 2005, 121, 579-591. [CrossRef] [PubMed]

89. Li, P.; Nijhawan, D.; Budihardjo, I.; Srinivasula, S.M.; Ahmad, M.; Alnemri, E.S.; Wang, X. Cytochrome c and datp-dependent formation of Apaf-1/caspase-9 complex initiates an apoptotic protease cascade. Cell 1997, 91, 479-489. [CrossRef]

90. Li, L.Y.; Luo, X.; Wang, X. Endonuclease G is an apoptotic dnase when released from mitochondria. Nature 2001, 412, 95-99. [CrossRef] [PubMed] 
91. Bobrovnikova-Marjon, E.; Grigoriadou, C.; Pytel, D.; Zhang, F.; Ye, J.; Koumenis, C.; Cavener, D.; Diehl, J.A. PERK promotes cancer cell proliferation and tumor growth by limiting oxidative DNA damage. Oncogene 2010, 29, 3881-3895. [CrossRef] [PubMed]

92. Xie, J.; Xu, Y.; Huang, X.; Chen, Y.; Fu, J.; Xi, M.; Wang, L. Berberine-induced apoptosis in human breast cancer cells is mediated by reactive oxygen species generation and mitochondrial-related apoptotic pathway. Tumor Biol. 2015, 36, 1279-1288. [CrossRef] [PubMed]

93. Huang, T.-C.; Chen, J.-Y. Proteomic analysis reveals that pardaxin triggers apoptotic signaling pathways in human cervical carcinoma hela cells: Cross talk among the UPR, c-Jun and ROS. Carcinogenesis 2013, 34, 1833-1842. [CrossRef] [PubMed]

94. Gutiérrez-Rodríguez, A.G.; Juárez-Portilla, C.; Olivares-Bañuelos, T.; Zepeda, R.C. Anticancer activity of seaweeds. Drug Discov. Today 2018, 23, 434-437. [CrossRef] [PubMed]

95. Cragg, G.M.; Grothaus, P.G.; Newman, D.J. Impact of natural products on developing new anti-cancer agents. Chem. Rev. 2009, 109, 3012-3043. [CrossRef] [PubMed]

96. Kelloff, G.J.; Crowell, J.A.; Steele, V.E.; Lubet, R.A.; Malone, W.A.; Boone, C.W.; Kopelovich, L.; Hawk, E.T.; Lieberman, R.; Lawrence, J.A. Progress in cancer chemoprevention: Development of diet-derived chemopreventive agents. J. Nutr. 2000, 130, 467S-471S. [CrossRef] [PubMed]

97. Sharma, S.; Stutzman, J.D.; Kelloff, G.J.; Steele, V.E. Screening of potential chemopreventive agents using biochemical markers of carcinogenesis. Cancer Res. 1994, 54, 5848-5855. [PubMed]

98. Mann, J. Natural products in cancer chemotherapy: Past, present and future. Nat. Rev. Cancer. 2002, 2, 143-148. [CrossRef] [PubMed]

99. Kim, C.; Song, H.S.; Park, H.; Kim, B. Activation of ER stress-dependent miR-216b has a critical role in salviamiltiorrhiza ethanol-extract-induced apoptosis in U266 and U937 cells. Int. J. Mol. Sci. 2018, 19. [CrossRef] [PubMed]

100. Cha, J.A.; Song, H.-S.; Kang, B.; Park, M.N.; Park, K.S.; Kim, S.-H.; Shim, B.-S.; Kim, B. Mir-211 plays a critical role in cnidium officinale makino extract-induced, ROS/ER stress-mediated apoptosis in U937 and U266 cells. Int. J. Mol. Sci. 2018, 19, 865. [CrossRef] [PubMed]

101. Park, S.K.; Sanders, B.G.; Kline, K. Tocotrienols induce apoptosis in breast cancer cell lines via an endoplasmic reticulum stress-dependent increase in extrinsic death receptor signaling. Breast Cancer Res. Treat. 2010, 124, 361-375. [CrossRef] [PubMed]

102. Al Husaini, H.; Wheatley-Price, P.; Clemons, M.; Shepherd, F.A. Prevention and management of bone metastases in lung cancer: A review. J. Thorac. Oncol. 2009, 4, 251-259. [CrossRef] [PubMed]

103. Qazi, A.K.; Siddiqui, J.A.; Jahan, R.; Chaudhary, S.; Walker, L.A.; Sayed, Z.; Jones, D.T.; Batra, S.K.; Macha, M.A. Emerging therapeutic potential of graviola and its constituents in cancers. Carcinogenesis 2018, 39, 522-533. [CrossRef] [PubMed]

104. Marciniak, S.J. Endoplasmic reticulum stress in lung disease. Eur. Respir. Rev. 2017, 26. [CrossRef] [PubMed]

105. Siu, F.M.; Ma, D.L.; Cheung, Y.W.; Lok, C.N.; Yan, K.; Yang, Z.; Yang, M.; Xu, S.; Ko, B.C.; He, Q.Y.; et al. Proteomic and transcriptomic study on the action of a cytotoxic saponin (polyphyllin D): Induction of endoplasmic reticulum stress and mitochondria-mediated apoptotic pathways. Proteomics 2008, 8, 3105-3117. [CrossRef] [PubMed]

106. Hung, J.Y.; Hsu, Y.L.; Ni, W.C.; Tsai, Y.M.; Yang, C.J.; Kuo, P.L.; Huang, M.S. Oxidative and endoplasmic reticulum stress signaling are involved in dehydrocostuslactone-mediated apoptosis in human non-small cell lung cancer cells. Lung Cancer 2010, 68, 355-365. [CrossRef] [PubMed]

107. Moon, J.L.; Kim, S.Y.; Shin, S.W.; Park, J.-W. Regulation of brefeldin A-induced ER stress and apoptosis by mitochondrial NADP+-dependent isocitrate dehydrogenase. Biochem. Biophys. Res. Commun. 2012, 417, 760-764. [CrossRef] [PubMed]

108. Yang, K.M.; Kim, B.M.; Park, J.B. Omega-hydroxyundec-9-enoic acid induces apoptosis through ROS-mediated endoplasmic reticulum stress in non-small cell lung cancer cells. Biochem. Biophys. Res. Commun. 2014, 448, 267-273. [CrossRef] [PubMed]

109. Wu, S.-H.; Hang, L.-W.; Yang, J.-S.; Chen, H.-Y.; Lin, H.-Y.; Chiang, J.-H.; Lu, C.-C.; Yang, J.-L.; Lai, T.-Y.; Ko, Y.-C. Curcumin induces apoptosis in human non-small cell lung cancer NCI-h460 cells through er stress and caspase cascade-and mitochondria-dependent pathways. Anticancer Res. 2010, 30, 2125-2133. [PubMed] 
110. Hsia, T.C.; Yu, C.C.; Hsu, S.C.; Tang, N.Y.; Lu, H.F.; Huang, Y.P.; Wu, S.H.; Lin, J.G.; Chung, J.G. Cantharidin induces apoptosis of h460 human lung cancer cells through mitochondria-dependent pathways. Int. J. Oncol. 2014, 45, 245-254. [CrossRef] [PubMed]

111. Xu, W.S.; Dang, Y.Y.; Guo, J.J.; Wu, G.S.; Lu, J.J.; Chen, X.P.; Wang, Y.T. Furanodiene induces endoplasmic reticulum stress and presents antiproliferative activities in lung cancer cells. Evid.-Based Complement. Altern. Med. ECAM. 2012, 2012, 426521. [CrossRef] [PubMed]

112. Zhao, X.; Liu, X.; Su, L. Parthenolide induces apoptosis via tnfrsf10b and pmaip1 pathways in human lung cancer cells. J. Exp. Clin. Cancer Res. 2014, 33, 3. [CrossRef] [PubMed]

113. Seong, Y.A.; Shin, P.G.; Yoon, J.S.; Yadunandam, A.K.; Kim, G.D. Induction of the endoplasmic reticulum stress and autophagy in human lung carcinoma a549 cells by anacardic acid. Cell Biochem. Biophys. 2014, 68, 369-377. [CrossRef] [PubMed]

114. Clarke, R.; Cook, K.L.; Hu, R.; Facey, C.O.; Tavassoly, I.; Schwartz, J.L.; Baumann, W.T.; Tyson, J.J.; Xuan, J.; Wang, Y.; et al. Endoplasmic reticulum stress, the unfolded protein response, autophagy, and the integrated regulation of breast cancer cell fate. Cancer Res. 2012, 72, 1321-1331. [CrossRef] [PubMed]

115. Ko, E.-Y.; Moon, A. Natural products for chemoprevention of breast cancer. J. Cancer Prev. 2015, 20, $223-231$. [CrossRef] [PubMed]

116. Tseng, C.N.; Hong, Y.R.; Chang, H.W.; Yu, T.J.; Hung, T.W.; Hou, M.F.; Yuan, S.S.; Cho, C.L.; Liu, C.T.; Chiu, C.C.; et al. Brefeldin a reduces anchorage-independent survival, cancer stem cell potential and migration of MDA-MB-231 human breast cancer cells. Molecules 2014, 19, 17464-17477. [CrossRef] [PubMed]

117. Park, I.J.; Kim, M.J.; Park, O.J.; Choe, W.; Kang, I.; Kim, S.S.; Ha, J. Cryptotanshinone induces ER stress-mediated apoptosis in HEPG2 and MCF7 cells. Apoptosis 2012, 17, 248-257. [CrossRef] [PubMed]

118. Shi, J.M.; Bai, L.L.; Zhang, D.M.; Yiu, A.; Yin, Z.Q.; Han, W.L.; Liu, J.S.; Li, Y.; Fu, D.Y.; Ye, W.C. Saxifragifolin $\mathrm{D}$ induces the interplay between apoptosis and autophagy in breast cancer cells through ROS-dependent endoplasmic reticulum stress. Biochem. Pharmacol. 2013, 85, 913-926. [CrossRef] [PubMed]

119. Pan, M.Y.; Shen, Y.C.; Lu, C.H.; Yang, S.Y.; Ho, T.F.; Peng, Y.T.; Chang, C.C. Prodigiosin activates endoplasmic reticulum stress cell death pathway in human breast carcinoma cell lines. Toxicol. Appl. Pharmacol. 2012, 265, 325-334. [CrossRef] [PubMed]

120. Chen, S.; Zhao, Y.; Zhang, Y.; Zhang, D. Fucoidan induces cancer cell apoptosis by modulating the endoplasmic reticulum stress cascades. PLoS ONE 2014, 9, e108157. [CrossRef] [PubMed]

121. Kamiya, T.; Nishihara, H.; Hara, H.; Adachi, T. Ethanol extract of brazilian red propolis induces apoptosis in human breast cancer MCF-7 cells through endoplasmic reticulum stress. J. Agric. Food Chem. 2012, 60, 11065-11070. [CrossRef] [PubMed]

122. Zhou, Y.; Shu, F.; Liang, X.; Chang, H.; Shi, L.; Peng, X.; Zhu, J.; Mi, M. Ampelopsin induces cell growth inhibition and apoptosis in breast cancer cells through ROS generation and endoplasmic reticulum stress pathway. PLoS ONE 2014, 9, e89021. [CrossRef] [PubMed]

123. Qazi, A.K.; Hussain, A.; Aga, M.A.; Ali, S.; Taneja, S.C.; Sharma, P.R.; Saxena, A.K.; Mondhe, D.M.; Hamid, A. Cell specific apoptosis by RLX is mediated by NFKB in human colon carcinoma HCT-116 cells. BMC Cell Biol. 2014, 15, 36. [CrossRef] [PubMed]

124. Wielenga, M.C.B.; Colak, S.; Heijmans, J.; van Lidth de Jeude, J.F.; Rodermond, H.M.; Paton, J.C.; Paton, A.W.; Vermeulen, L.; Medema, J.P.; van den Brink, G.R. ER-stress-induced differentiation sensitizes colon cancer stem cells to chemotherapy. Cell Rep. 2015, 13, 489-494. [CrossRef] [PubMed]

125. Cao, A.; Li, Q.; Yin, P.; Dong, Y.; Shi, H.; Wang, L.; Ji, G.; Xie, J.; Wu, D. Curcumin induces apoptosis in human gastric carcinoma ags cells and colon carcinoma HT-29 cells through mitochondrial dysfunction and endoplasmic reticulum stress. Apoptosis 2013, 18, 1391-1402. [CrossRef] [PubMed]

126. Guichard, C.; Pedruzzi, E.; Fay, M.; Marie, J.C.; Braut-Boucher, F.; Daniel, F.; Grodet, A.; Gougerot-Pocidalo, M.A.; Chastre, E.; Kotelevets, L.; et al. Dihydroxyphenylethanol induces apoptosis by activating serine/threonine protein phosphatase PP2A and promotes the endoplasmic reticulum stress response in human colon carcinoma cells. Carcinogenesis 2006, 27, 1812-1827. [CrossRef] [PubMed]

127. Tseng, C.N.; Huang, C.F.; Cho, C.L.; Chang, H.W.; Huang, C.W.; Chiu, C.C.; Chang, Y.F. Brefeldin a effectively inhibits cancer stem cell-like properties and mmp-9 activity in human colorectal cancer colo 205 cells. Molecules 2013, 18, 10242-10253. [CrossRef] [PubMed] 
128. Park, J.-W.; Woo, K.J.; Lee, J.-T.; Lim, J.H.; Lee, T.-J.; Kim, S.H.; Choi, Y.H.; Kwon, T.K. Resveratrol induces pro-apoptotic endoplasmic reticulum stress in human colon cancer cells. Oncol. Rep. 2007, 18, 1269-1273. [CrossRef] [PubMed]

129. Edagawa, M.; Kawauchi, J.; Hirata, M.; Goshima, H.; Inoue, M.; Okamoto, T.; Murakami, A.; Maehara, Y.; Kitajima, S. Role of activating transcription factor 3 (ATF3) in endoplasmic reticulum (ER) stress-induced sensitization of p53-deficient human colon cancer cells to tumor necrosis factor (TNF)-related apoptosis-inducing ligand (TRAIL)-mediated apoptosis through up-regulation of death receptor 5 (DR5) by zerumbone and celecoxib. J. Biol. Chem. 2014, 289, 21544-21561. [PubMed]

130. Protiva, P.; Hopkins, M.E.; Baggett, S.; Yang, H.; Lipkin, M.; Holt, P.R.; Kennelly, E.J.; Bernard, W.I. Growth inhibition of colon cancer cells by polyisoprenylated benzophenones is associated with induction of the endoplasmic reticulum response. Int. J. Cancer 2008, 123, 687-694. [CrossRef] [PubMed]

131. Yaffe, P.B.; Power Coombs, M.R.; Doucette, C.D.; Walsh, M.; Hoskin, D.W. Piperine, an alkaloid from black pepper, inhibits growth of human colon cancer cells via G1 arrest and apoptosis triggered by endoplasmic reticulum stress. Mol. Carcinogenesis 2015, 54, 1070-1085. [CrossRef] [PubMed]

132. Kuo, Y.F.; Su, Y.Z.; Tseng, Y.H.; Wang, S.Y.; Wang, H.M.; Chueh, P.J. Flavokawain B, a novel chalcone from alpinia pricei Hayata with potent apoptotic activity: Involvement of ros and GADD153 upstream of mitochondria-dependent apoptosis in HCT116 cells. Free Radic. Biol. Med. 2010, 49, 214-226. [CrossRef] [PubMed]

133. Mullen, J.T.; Ryan, D.P. Neoadjuvant chemotherapy for gastric cancer: What are we trying to accomplish? Ann. Surg. Oncol. 2014, 21, 13-15. [CrossRef] [PubMed]

134. Boelens, J.; Lust, S.; Offner, F.; Bracke, M.E.; Vanhoecke, B.W. The endoplasmic reticulum: A target for new anticancer drugs. In Vivo 2007, 21, 215-226. [PubMed]

135. Ahn, J.; Lee, J.S.; Yang, K.M. Ultrafine particles of Ulmus davidiana var. japonica induce apoptosis of gastric cancer cells via activation of caspase and endoplasmic reticulum stress. Arch. Pharm. Res. 2014, 37, 783-792. [CrossRef] [PubMed]

136. Sheu, M.L.; Liu, S.H.; Lan, K.H. Honokiol induces calpain-mediated glucose-regulated protein-94 cleavage and apoptosis in human gastric cancer cells and reduces tumor growth. PLoS ONE 2007, 2, e1096. [CrossRef] [PubMed]

137. Huang, X.; Zhang, Z.; Jia, L.; Zhao, Y.; Zhang, X.; Wu, K. Endoplasmic reticulum stress contributes to vitamin E succinate-induced apoptosis in human gastric cancer SGC-7901 cells. Cancer Lett. 2010, 296, 123-131. [CrossRef] [PubMed]

138. Huang, X.; Li, L.; Zhang, L.; Zhang, Z.; Wang, X.; Zhang, X.; Hou, L.; Wu, K. Crosstalk between endoplasmic reticulum stress and oxidative stress in apoptosis induced by alpha-tocopheryl succinate in human gastric carcinoma cells. Br. J. Nutr. 2013, 109, 727-735. [CrossRef] [PubMed]

139. Zhou, Y.; Tian, L.; Long, L.; Quan, M.; Liu, F.; Cao, J. Casticin potentiates trail-induced apoptosis of gastric cancer cells through endoplasmic reticulum stress. PLoS ONE 2013, 8, e58855. [CrossRef] [PubMed]

140. Zou, P.; Zhang, J.; Xia, Y.; Kanchana, K.; Guo, G.; Chen, W.; Huang, Y.; Wang, Z.; Yang, S.; Liang, G. ROS generation mediates the anti-cancer effects of WZ35 via activating JNK and ER stress apoptotic pathways in gastric cancer. Oncotarget 2015, 6, 5860. [CrossRef] [PubMed]

141. Kallifatidis, G.; Hoy, J.J.; Lokeshwar, B.L. Bioactive Natural products for chemoprevention and treatment of castration-resistant prostate cancer. Semin. Cancer Biol. 2016, 160-169. [CrossRef] [PubMed]

142. Miyake, H.; Hara, I.; Arakawa, S.; Kamidono, S. Stress protein GRP78 prevents apoptosis induced by calcium ionophore, ionomycin, but not by glycosylation inhibitor, tunicamycin, in human prostate cancer cells. J. Cell. Biochem. 2000, 77, 396-408. [CrossRef]

143. Yu, C.C.; Wu, P.J.; Hsu, J.L.; Ho, Y.F.; Hsu, L.C.; Chang, Y.J.; Chang, H.S.; Chen, I.S.; Guh, J.H. Ardisianone, a natural benzoquinone, efficiently induces apoptosis in human hormone-refractory prostate cancers through mitochondrial damage stress and survivin downregulation. Prostate 2013, 73, 133-145. [CrossRef] [PubMed]

144. Rizzi, F.; Naponelli, V.; Silva, A.; Modernelli, A.; Ramazzina, I.; Bonacini, M.; Tardito, S.; Gatti, R.; Uggeri, J.; Bettuzzi, S. Polyphenon E(R), a standardized green tea extract, induces endoplasmic reticulum stress, leading to death of immortalized pnt1a cells by anoikis and tumorigenic PC3 by necroptosis. Carcinogenesis 2014, 35, 828-839. [CrossRef] [PubMed] 
145. Li, G.; Petiwala, S.M.; Pierce, D.R.; Nonn, L.; Johnson, J.J. Selective modulation of endoplasmic reticulum stress markers in prostate cancer cells by a standardized mangosteen fruit extract. PLoS ONE 2013, 8, e81572. [CrossRef] [PubMed]

146. Jiang, H.; Sun, J.; Xu, Q.; Liu, Y.; Wei, J.; Young, C.Y.; Yuan, H.; Lou, H. Marchantin M: A novel inhibitor of proteasome induces autophagic cell death in prostate cancer cells. Cell Death Dis. 2013, 4, e761. [CrossRef] [PubMed]

147. Chiu, H.W.; Fang, W.H.; Chen, Y.L.; Wu, M.D.; Yuan, G.F.; Ho, S.Y.; Wang, Y.J. Monascuspiloin enhances the radiation sensitivity of human prostate cancer cells by stimulating endoplasmic reticulum stress and inducing autophagy. PLoS ONE 2012, 7, e40462. [CrossRef] [PubMed]

148. Liu, K.C.; Yen, C.Y.; Wu, R.S.; Yang, J.S.; Lu, H.F.; Lu, K.W.; Lo, C.; Chen, H.Y.; Tang, N.Y.; Wu, C.C.; et al. The roles of endoplasmic reticulum stress and mitochondrial apoptotic signaling pathway in quercetin-mediated cell death of human prostate cancer PC-3 cells. Environ. Toxicol. 2014, 29, 428-439. [CrossRef] [PubMed]

149. Chan, M.L.; Liang, J.W.; Hsu, L.C.; Chang, W.L.; Lee, S.S.; Guh, J.H. Zerumbone, a ginger sesquiterpene, induces apoptosis and autophagy in human hormone-refractory prostate cancers through tubulin binding and crosstalk between endoplasmic reticulum stress and mitochondrial insult. Naunyn-Schmiedeberg's Arch. Pharmacol. 2015, 388, 1223-1236. [CrossRef] [PubMed]

150. Spangenberg, H.C.; Thimme, R.; Blum, H.E. Targeted therapy for hepatocellular carcinoma. Nature Reviews Gastroenterol. Hepatol. 2009, 6, 423-432. [CrossRef] [PubMed]

151. Carr, B.I. Hepatocellular carcinoma: Current management and future trends. Gastroenterology 2004, 127, S218-S224. [CrossRef] [PubMed]

152. Malhi, H.; Kaufman, R.J. Endoplasmic reticulum stress in liver disease. J. Hepatol. 2011, 54, 795-809. [CrossRef] [PubMed]

153. Choi, A.Y.; Choi, J.H.; Hwang, K.Y.; Jeong, Y.J.; Choe, W.; Yoon, K.S.; Ha, J.; Kim, S.S.; Youn, J.H.; Yeo, E.J.; et al. Licochalcone a induces apoptosis through endoplasmic reticulum stress via a phospholipase cgamma1-, $\mathrm{Ca}(2+)-$, and reactive oxygen species-dependent pathway in HepG2 human hepatocellular carcinoma cells. Apoptosis 2014, 19, 682-697. [CrossRef] [PubMed]

154. Moon, D.O.; Park, S.Y.; Choi, Y.H.; Ahn, J.S.; Kim, G.Y. Guggulsterone sensitizes hepatoma cells to trail-induced apoptosis through the induction of chop-dependent DR5: Involvement of ros-dependent er-stress. Biochem. Pharmacol. 2011, 82, 1641-1650. [CrossRef] [PubMed]

155. Moon, D.O.; Asami, Y.; Long, H.; Jang, J.H.; Bae, E.Y.; Kim, B.Y.; Choi, Y.H.; Kang, C.H.; Ahn, J.S.; Kim, G.Y. Verrucarin a sensitizes trail-induced apoptosis via the upregulation of DR5 in an eIF2alpha/CHOP-dependent manner. Toxicol. In Vitro 2013, 27, 257-263. [CrossRef] [PubMed]

156. Yang, J.F.; Cao, J.G.; Tian, L.; Liu, F. 5, 7-dimethoxyflavone sensitizes trail-induced apoptosis through DR5 upregulation in hepatocellular carcinoma cells. Cancer Chemother. Pharmacol. 2012, 69, 195-206. [CrossRef] [PubMed]

157. Yoon, J.S.; Kim, H.M.; Yadunandam, A.K.; Kim, N.H.; Jung, H.A.; Choi, J.S.; Kim, C.Y.; Kim, G.D. Neferine isolated from nelumbo nucifera enhances anti-cancer activities in Hep3B cells: Molecular mechanisms of cell cycle arrest, ER stress induced apoptosis and anti-angiogenic response. Phytomedicine 2013, 20, 1013-1022. [CrossRef] [PubMed]

158. Fan, L.; Song, B.; Sun, G.; Ma, T.; Zhong, F.; Wei, W. Endoplasmic reticulum stress-induced resistance to doxorubicin is reversed by paeonol treatment in human hepatocellular carcinoma cells. PLoS ONE 2013, 8, e62627. [CrossRef] [PubMed]

159. Hu, R.; Zhou, P.; Peng, Y.-B.; Xu, X.; Ma, J.; Liu, Q.; Zhang, L.; Wen, X.-D.; Qi, L.-W.; Gao, N. 6-shogaol induces apoptosis in human hepatocellular carcinoma cells and exhibits anti-tumor activity in vivo through endoplasmic reticulum stress. PLoS ONE 2012, 7, e39664. [CrossRef] [PubMed]

160. Yeh, T.C.; Chiang, P.C.; Li, T.K.; Hsu, J.L.; Lin, C.J.; Wang, S.W.; Peng, C.Y.; Guh, J.H. Genistein induces apoptosis in human hepatocellular carcinomas via interaction of endoplasmic reticulum stress and mitochondrial insult. Biochem. Pharmacol. 2007, 73, 782-792. [CrossRef] [PubMed]

161. Richardson, J.L.; Marks, G.; Levine, A. The influence of symptoms of disease and side effects of treatment on compliance with cancer therapy. J. Clin. Oncol. 1988, 6, 1746-1752. [CrossRef] [PubMed]

162. Coates, A.; Abraham, S.; Kaye, S.B.; Sowerbutts, T.; Frewin, C.; Fox, R.; Tattersall, M. On the receiving end-Patient perception of the side-effects of cancer chemotherapy. Eur. J. Cancer Clin. Oncol. 1983, 19, 203-208. [CrossRef] 
163. Tsuruo, T.; Naito, M.; Tomida, A.; Fujita, N.; Mashima, T.; Sakamoto, H.; Haga, N. Molecular targeting therapy of cancer: Drug resistance, apoptosis and survival signal. Cancer Sci. 2003, 94, 15-21. [CrossRef] [PubMed]

164. Shuda, M.; Kondoh, N.; Imazeki, N.; Tanaka, K.; Okada, T.; Mori, K.; Hada, A.; Arai, M.; Wakatsuki, T.; Matsubara, O. Activation of the ATF6, XBP1 and GRP78 genes in human hepatocellular carcinoma: A possible involvement of the ER stress pathway in hepatocarcinogenesis. J. Hepatol. 2003, 38, 605-614. [CrossRef]

165. Corazzari, M.; Lovat, P.E.; Armstrong, J.L.; Fimia, G.M.; Hill, D.S.; Birch-Machin, M.; Redfern, C.P.F.; Piacentini, M. Targeting homeostatic mechanisms of endoplasmic reticulum stress to increase susceptibility of cancer cells to fenretinide-induced apoptosis: The role of stress proteins ERDJ5 and ERP57. Br. J. Cancer. 2007, 96, 1062-1071. [CrossRef] [PubMed]

166. Gray, M.D.; Mann, M.; Nitiss, J.L.; Hendershot, L.M. Activation of the unfolded protein response is necessary and sufficient for reducing topoisomerase IIA protein levels and decreasing sensitivity to topoisomerase-targeted drugs. Mol. Pharmacol. 2005, 68, 1699-1707. [PubMed]

167. Malhotra, J.D.; Kaufman, R.J. Endoplasmic reticulum stress and oxidative stress: A vicious cycle or a double-edged sword? Antioxid. Redox Signal. 2007, 9, 2277-2294. [CrossRef] [PubMed]

168. Da Rocha, A.B.; Lopes, R.M.; Schwartsmann, G. Natural products in anticancer therapy. Curr. Opin. Pharmacol. 2001, 1, 364-369. [CrossRef]

169. Gordaliza, M. Natural products as leads to anticancer drugs. Clin. Transl. Oncol. 2007, 9, 767-776. [CrossRef] [PubMed]

170. López-Antón, N.; Rudy, A.; Barth, N.; Schmitz, L.M.; Pettit, G.R.; Schulze-Osthoff, K.; Dirsch, V.M.; Vollmar, A.M. The marine product cephalostatin 1 activates an endoplasmic reticulum stress-specific and apoptosome-independent apoptotic signaling pathway. J. Biol. Chem. 2006, 281, 33078-33086. [CrossRef] [PubMed]

171. Law, B.Y.; Wang, M.; Ma, D.-L.; Al-Mousa, F.; Michelangeli, F.; Cheng, S.-H.; Ng, M.H.; To, K.-F.; Mok, A.Y.; Ko, R.Y. Alisol B, a novel inhibitor of the sarcoplasmic/endoplasmic reticulum $\mathrm{Ca}^{2+}$ atpase pump, induces autophagy, endoplasmic reticulum stress, and apoptosis. Mol. Cancer Ther. 2010, 9, 718-730. [CrossRef] [PubMed]

172. Carew, J.S.; Nawrocki, S.T.; Krupnik, Y.V.; Dunner, K.; McConkey, D.J.; Keating, M.J.; Huang, P. Targeting endoplasmic reticulum protein transport: A novel strategy to kill malignant B cells and overcome fludarabine resistance in CLL. Blood 2006, 107, 222-231. [CrossRef] [PubMed]

173. Chen, T.C.; Wang, W.; Golden, E.B.; Thomas, S.; Sivakumar, W.; Hofman, F.M.; Louie, S.G.; Schonthal, A.H. Green tea epigallocatechin gallate enhances therapeutic efficacy of temozolomide in orthotopic mouse glioblastoma models. Cancer Lett. 2011, 302, 100-108. [CrossRef] [PubMed]

174. Lu, T.; Gu, M.; Zhao, Y.; Zheng, X.; Xing, C. Autophagy contributes to falcarindiol-induced cell death in breast cancer cells with enhanced endoplasmic reticulum stress. PLoS ONE 2017, 12, e0176348. [CrossRef] [PubMed]

175. Dolan, L.C.; Matulka, R.A.; Burdock, G.A. Naturally occurring food toxins. Toxins 2010, 2, $2289-2332$. [CrossRef] [PubMed]

176. Ibrahim, M.Y.; Abdul, A.; Ibrahim, T.A.T.; Abdelwahab, S.I.; Elhassan, M.M.; Syam, M. Evaluation of acute toxicity and the effect of single injected doses of zerumbone on the kidney and liver functions in sprague dawley rats. Afr. J. Biotechnol. 2010, 9, 4442-4450.

177. Chang, P.Y.; Mirsalis, J.; Riccio, E.S.; Bakke, J.P.; Lee, P.S.; Shimon, J.; Phillips, S.; Fairchild, D.; Hara, Y.; Crowell, J.A. Genotoxicity and toxicity of the potential cancer-preventive agent polyphenon e. Environ. Mol. Mutagenesis 2003, 41, 43-54. [CrossRef] [PubMed]

178. Yoshida, H. ER stress and diseases. FEBS J. 2007, 274, 630-658. [CrossRef] [PubMed]

179. Salminen, A.; Kauppinen, A.; Suuronen, T.; Kaarniranta, K.; Ojala, J. ER stress in Alzheimer's disease: A novel neuronal trigger for inflammation and alzheimer's pathology. J. Neuroinflamm. 2009, 6, 41. [CrossRef] [PubMed]

(C) 2018 by the authors. Licensee MDPI, Basel, Switzerland. This article is an open access article distributed under the terms and conditions of the Creative Commons Attribution (CC BY) license (http:/ / creativecommons.org/licenses/by/4.0/). 